\title{
Mechanisms of tumor cell resistance to the current targeted-therapy agents
}

\author{
Gholamreza Khamisipour $^{1}$ - Farhad Jadidi-Niaragh ${ }^{2,3,4}$. \\ Abdolreza Sotoodeh Jahromi ${ }^{5}$ - Keivan zandi ${ }^{6}$ • Mohammad Hojjat-Farsangi ${ }^{7,8}$
}

Received: 18 February 2016 / Accepted: 1 May 2016 /Published online: 7 May 2016

(C) International Society of Oncology and BioMarkers (ISOBM) 2016

\begin{abstract}
Resistance to chemotherapy agents is a major challenge infront of cancer patient treatment and researchers. It is known that several factors, such as multidrug resistance proteins and ATP-binding cassette families, are cell membrane transporters that can efflux several substrates such as chemotherapy agents from the cell cytoplasm. To reduce the adverse effects of chemotherapy agents, various targeted-based cancer therapy (TBCT) agents have been developed. TBCT has revolutionized cancer treatment, and several agents have shown more specific effects on tumor cells than chemotherapies. Small molecule inhibitors and monoclonal antibodies are specific agents that mostly target tumor cells but have low side effects on normal cells. Although these agents have been very
\end{abstract}

Mohammad Hojjat-Farsangi

mohammad.hojat-farsangi@Ki.se

1 Department of Hematology, Faculty of Allied Medicine, Bushehr University of Medical Sciences, Bushehr, Iran

2 Department of Immunology, School of Public Health, Tehran University of Medical Sciences, Tehran, Iran

3 Immunology Research Center, Tabriz University of Medical Sciences, Tabriz, Iran

4 Department of Immunology, Faculty of Medicine, Tabriz University of Medical Sciences, Tabriz, Iran

5 Research Center for Non-Communicable Diseases, Jahrom University of Medical Sciences, Jahrom, Iran

6 Tropical Infectious Diseases Research and Education Center, Department of Medical Microbiology, Faculty of Medicine, University of Malaya, Kuala Lumpur, Malaysia

7 Department of Oncology-Pathology, Immune and Gene therapy Lab, Cancer Center Karolinska (CCK), Karolinska University Hospital Solna and Karolinska Institutet, SE-171 76 Stockholm, Sweden

8 Department of Immunology, School of Medicine, Bushehr University of Medical Sciences, Bushehr, Iran useful for cancer treatment, however, the presence of natural and acquired resistance has blunted the advantages of targeted therapies. Therefore, development of new options might be necessary. A better understanding of tumor cell resistance mechanisms to current treatment agents may provide an appropriate platform for developing and improving new treatment modalities. Therefore, in this review, different mechanisms of tumor cell resistance to chemotherapy drugs and current targeted therapies have been described.

Keywords Drug resistance · Small molecule inhibitors · Monoclonal antibodies · Chemotherapy $\cdot$ Targeted-based cancer therapy $\cdot$ Tyrosine kinase inhibitors

\section{Introduction}

After cardiovascular diseases, cancer is the second common cause of death, which is demonstrated by massive cell proliferation and cell death defects. Cancer is initiated by various factors, such as impairment and mutations of tumor suppressor genes and proteins [1].

For several years, chemotherapy has been one of the main anti-cancer treatments. Chemotherapy agents inhibit the rapidly dividing cancer and normal cells (e.g., hair follicles, bone marrow, and gastrointestinal cells). In addition to sever effects of chemotherapy agents, drug resistance develops after treatment regimens [2]. Therefore, development of new modalities such as targeted-based cancer therapy (TBCT) agents is necessary [3-5].

TBCT is a major and hot research topic in cancer treatment field and currently the US Food and Drug Administration (FDA), European Medical Agency (EMA) and other authorities in different countries are evaluating and approving various agents, including small molecule inhibitors (SMIs) and 
monoclonal antibodies $(\mathrm{mAb})[6]$. These agents target specific molecules and block biologic transduction pathways, which have been overexpressed or hyperactivated, respectively, by tumor cells. However, consistent findings have indicated that similar to chemotherapy, drug resistance to TBCT appeared in most patients $[1,7,8]$.

Resistance to cancer target therapies is divided into intrinsic (primary, first-line, or natural) and acquired (secondary, second-line) resistances that are due to the natural factors exist before treatments or are secondary to drug treatments, respectively [9].

During and after treatment, tumorigenic cells exist, but they are not able to produce another tumor population due to the pressure of drugs [10]. However, acquisition of various mutations, such as single nucleotide polymorphisms (SNPs) in target molecule [11], crosstalk between signaling pathways, presence of tumor subpopulation cells, such as cancer stem cells (CSCs) $[9,10,12]$, and dysregulation of DNA damage repair proteins that appear during or after treatment are the most important reasons for resistance to therapy (Tables 1 and 2) $[13,14]$.

Several studies suggested that using multi-targeted therapies, such as adenosine 3 phosphate (ATP)-competitive multitargeted inhibitors (type I SMIs) or mAbs, as well as long-term therapy, may decrease the abundance of resistant tumor cells or prevent drug resistance $[5,9,15]$. Whether such approaches are applicable or not need a better understanding of tumor biology and the mechanisms underlying the tumor cell resistance to current cancer drugs.

In this review, the most important mechanisms of drug resistance in different tumors have been described. This article tried to provide a clear picture of drug resistance mechanisms for researchers and physicians to develop new treatment modalities or improve the treatment choices.

\section{Types of drug resistance}

Development of cancer drug resistance is the main reason for poor prognosis of cancer as an incurable disease. Resistance to the present therapies can be divided into two main categories, including the intrinsic and acquired resistances [9]. Intrinsic resistance exists naturally before any treatment; however, acquired resistance develops during or after the treatment process of malignant cells, which have been responsive to the former treatments (Table 1) [16].

Intrinsic and acquired resistances have been shown for most chemotherapy and targeted-therapy drugs in various malignancies. It should be noted that some mechanisms of drug resistance can be categorized in both natural and acquired resistance. In the following sections, different mechanisms of natural and acquired resistance have been described.

\section{Natural resistance factors}

Several factors have been noted to contribute to natural resistance. The presence of heterogeneous populations of tumor cells, such as CSCs, changes in drug metabolism, expression of drug resistance proteins in tumor cells, modified expression of target protein, dysregulation of apoptosis, high activity of DNA damage repair system, which is expressed by tumor cells, bone marrow microenvironment, and steric hindrance are among the most important factors that are involved in resistance of cancer cells to treatment agents (Tables 1 and 2).

\section{Heterogeneity of tumor cells before treatment}

One of the major reasons for intrinsic/acquired drug resistance is the presence of tumor subpopulation cells that are resistant to different types of drugs and may arise during treatment process (Fig. 1).

Previously, it was believed that tumors are the homogenous population of dividing cells. However, this theory has been replaced, and currently, it is known that cancers are consisting of the heterogenic population of cells with a great degree of genetic and phenotypic heterogeneity. In a given type of tumor, cancer cells are heterogeneous, and various populations of cells with several clonogenic potentials and capabilities exist $[16,17]$. These populations are consisted of major and minor populations of tumor cells. During the treatment, the major populations are usually destroyed by cancer drugs and the minor resistant populations such as CSCs survive and remain quiescent due to drug pressure. Based on different conditions, such as the status of the immune system, age, and hormones, these minor populations may start to repopulate and establish another tumor, which is resistant to the firstline treatment [12].

Several kinds of research have shown that treatment failure in several tumors has been attributed to the presence of CSCs [16-19]. These cells are naturally extremely resistant to different therapeutic approaches (Fig. 1). Therefore, identification and characterization of normal and CSCs are major research areas of TBCT and have been described in the following section.

Stem cells are a minor population of cells and have the potential to differentiate into different types of cells. In several tissues, they function as a type of repair system, dividing without limit to repopulate other cells. Each new population of cells (originated from stem cells) has the capacity either to remain a stem cell or change to other types of more specialized cells with a define function, such as a brain and muscle cells [20, 21].

Two essential characteristics distinguished stem cells from other cell types. First, they are undifferentiated cells with renewing capacity (cell division) and might be inactive for a long period. Second, they can differentiate and become a 
Table 1 Mechanisms of resistance to current targeted therapies

\begin{tabular}{ll}
\hline Type & Mechanism of resistance \\
\hline $\begin{array}{l}\text { Intrinsic } \\
\text { resistance }\end{array}$ & \\
1 & Heterogeneity of tumor cells before treatment \\
2 & Cancer stem cells \\
3 & Changes in drug metabolism (increased efflux of drugs from tumor cell membrane) and drug \\
& inactivation \\
4 & Expression of drug resistance proteins \\
5 & Extracellular vesicles \\
7 & Low/overexpression of the target protein \\
8 & Inefficient or dysregulation of apoptotic machinery \\
9 & DNA damage repair \\
10 & Bone marrow microenvironment \\
Acquired & Steric hindrance \\
1 & \\
2 & resistance \\
3 & Heterogeneity of tumor cells after treatment \\
4 & Changes in drug targets: mutation and methylation \\
5 & Mutations in the target gene after treatment \\
6 & Hyperactivation of prosurvival signaling pathways \\
7 & Up/downregulation of miRNAs \\
\hline
\end{tabular}

tissue or an organ with specialized functions, when they activated under special conditions and environments. In several organs and tissues, such as bone marrow, these cells frequently divide to repair and substitute damaged cells or tissues. However, in other tissues, such as heart or pancreas, these cells only divide under special situations [20, 22, 23].

Currently, differentiating normal stem cells from CSCs is an important obstacle infront of researchers. Several investigations have shown that normal and CSCs might have similar differentiating marker profiles in the same tissues or organs. For example, normal mammary stem cells, as well as tumor cells in human breast cancer, have been shown to be CD24 negative $[24,25]$.

The presence of CSCs was initially described 20 years ago for acute myeloid leukemia (AML), and it was shown that these cells display the $\mathrm{CD} 34^{+} / \mathrm{CD} 38^{-}$phenotype and following transplantation into severe combined immunodeficiency (SCID) mice rise into tumor cells. Moreover, it was demonstrated that a small population of breast CSCs has the phenotype of CD $44^{+} / \mathrm{CD} 24^{-} / \mathrm{low} / \mathrm{Lin}^{-}$that were able to initiate tumor formation when transplanted into non-obese diabetic (NOD)/ SCID mice [26, 27].

Epidermal normal stem cells, as well as tumorigenic cells, are shown to be $\mathrm{CD} 34^{+}$in the chemically induced tumor of the skin (squamous cell carcinomas) in the mouse [28]. Several studies have described markers that differentiate normal and CSCs in the same tissues $[29,30]$. For example, CD26 has been demonstrated to be expressed by CSCs and is expressed in several types of cancer but not by normal stem cells. Moreover, its expression correlates with CSCs properties, such as the formation of new tumors, resistance to chemotherapy, and the formation of spheres in vitro [31]. Moreover, $\mathrm{CD} 4^{+} / \mathrm{CD} 38^{-} / \mathrm{CD} 3^{-} / \mathrm{CD}_{3} 3^{+} / \mathrm{CD} 0^{+} / \mathrm{CD} 123^{- \text {low }} / \mathrm{CD} 117^{+} /$ $\mathrm{CD} 1^{+}$phenotype has been described as the main phenotype of normal hematopoietic stem cells [32].

As described before, $\mathrm{CD} 34^{+} / \mathrm{CD} 38^{-} / \mathrm{Lin}^{-}$phenotype was the first that was described for leukemic stem cells in AML [33]. However, further studies have shown more complicated phenotype of CSCs. Several other markers, such as CD90, CD71, CD123, CD117, HLA-DR [34], and CD26 for chronic myeloid leukemia (CML) [35], CD33 for AML [36], and CD133 for acute lymphocytic leukemia (ALL) [37] have been suggested as CSC markers.

The presence of cisplatin-resistant cells $\left(\mathrm{CD} 133^{+}\right)$has been shown in non-small cell lung carcinoma (NSCLC) that also express CXC chemokine receptor (CXCR) 4 [38]. Moreover, several populations of highly quiescent cells that divide slowly have been noted. Treatment with all-trans retinoic acid and cisplatin has been effective on $\mathrm{CD} 133^{+} / \mathrm{CXCR}^{+}$cells in NSCLC [38].

The expression of CD133 and CXCR4 on CSCs has been evaluated in ovarian cancer cell lines [39]. Several ovarian cancer cell lines, such as OVCAR-3, -4, and -5 and colon cancer cells, SW620 and HCT-116 express both markers. 
Table 2 Mechanisms of drug resistance to the current targeted-therapy agents

\begin{tabular}{|c|c|c|c|c|}
\hline Name & Trade name & Selective target & Resistant cancers & $\begin{array}{l}\text { Mechanism of resistance } \\
\text { (examples) }\end{array}$ \\
\hline Afatinib & Gilotrif & HER2, EGFR, HER4 & $\begin{array}{l}\text { NSCLC, squamous cell } \\
\text { carcinoma of the head and } \\
\text { neck, breast cancer }\end{array}$ & $\begin{array}{l}\text { Overexpression/mutation in } \\
\text { targets }\end{array}$ \\
\hline Canertinib & ND & EGFR, HER2, HER4 & $\begin{array}{l}\text { Head and neck, breast, and } \\
\text { NSCLC, ovarian cancer }\end{array}$ & $\begin{array}{l}\text { Overexpression/mutation in } \\
\text { targets }\end{array}$ \\
\hline Cediranib & Recentin & VEGFR & $\begin{array}{l}\text { NSCLC, kidney and } \\
\text { colorectal cancer }\end{array}$ & $\begin{array}{l}\text { Overexpression/mutation in } \\
\text { targets, CSCs }\end{array}$ \\
\hline CР-673451 & ND & PDGFR & $\begin{array}{l}\text { NSCLC, colon carcinomas, } \\
\text { glioblastoma }\end{array}$ & $\begin{array}{l}\text { Upregulation of alternative pro- } \\
\text { angiogenic signaling } \\
\text { pathways, CSCs, } \\
\text { overexpression of ABC } \\
\text { family }\end{array}$ \\
\hline Crizotinib & Xalkori & MET & $\begin{array}{l}\text { NSCLC, anaplastic large cell } \\
\text { lymphoma, } \\
\text { neuroblastoma }\end{array}$ & Overexpression \\
\hline Crenolanib & ND & FLT3, PDGFR $\alpha / \beta$ & $\begin{array}{l}\text { AML, gastrointestinal } \\
\text { stromal tumor, glioma }\end{array}$ & Mutation in targets \\
\hline Cetuximab & Erbitux & EGFR & $\begin{array}{l}\text { Head and neck squamous } \\
\text { cell carcinoma, MCC }\end{array}$ & Mutation in targets \\
\hline Dacomitinib & ND & EGFR & $\begin{array}{l}\text { NSCLC, gastric, head and } \\
\text { neck/glioma }\end{array}$ & $\begin{array}{l}\text { Overexpression/mutation in } \\
\text { targets }\end{array}$ \\
\hline Erlotinib & Tarceva & EGFR & NSCLC, pancreatic cancer & $\begin{array}{l}\text { Overexpression/mutation in } \\
\text { targets, } \\
\text { chronopharmacology }\end{array}$ \\
\hline Gefitinib & Iressa & EGFR & NSCLC, AML & $\begin{array}{l}\text { Overexpression/mutation in } \\
\text { targets }\end{array}$ \\
\hline Icotinib & Conmana & EGFR & NSCLC & $\begin{array}{l}\text { Overexpression/mutation in } \\
\text { targets }\end{array}$ \\
\hline KW-2449 & ND & FLT3 & AML & Mutation in targets \\
\hline Lapatinib & Tykerb & HER-2, EGFR & Breast cancer & $\begin{array}{l}\text { Overexpression/mutation in } \\
\text { targets, enhanced HER2 } \\
\text { dimerization }\end{array}$ \\
\hline Lenvatinib & ND & VEGFR $2 / 3$ & $\begin{array}{l}\text { Approved for thyroid cancer } \\
\text { in Japan }\end{array}$ & $\mathrm{ABC}$ transporters, $\mathrm{CSCs}$ \\
\hline LY2801653 & ND & MET, RON & NSCLC & $\begin{array}{l}\text { Activation of compensatory } \\
\text { signaling pathways }\end{array}$ \\
\hline Neratinib & HKI-272 & EGFR, HER2 & NSCLC, breast cancer & $\begin{array}{l}\text { Overexpression/mutation in } \\
\text { targets, enhanced HER2 } \\
\text { dimerization }\end{array}$ \\
\hline PD-173074 & ND & FGFR & $\begin{array}{l}\text { NSCLC, gastric carcinoma, } \\
\text { breast cancer }\end{array}$ & Mutation in targets \\
\hline Quizartinib & ND & FLT3 & AML & Mutation in targets \\
\hline R428 (BGB-324) & ND & AXL & AML, NSCLC, breast cancer & $\begin{array}{l}\text { Reduced expression of miR- } \\
\quad 34 \mathrm{a}\end{array}$ \\
\hline Tandutinib & ND & FLT3 & RCC, CML & Mutation in targets \\
\hline Tivantinib & Arqule & MET & RCC, breast cancer & MET amplification \\
\hline trastuzumab & Herceptin (Herclon) & HER2 & $\begin{array}{l}\text { Breast cancer, gastric } \\
\text { adenocarcinoma, } \\
\text { gastroesophageal junction } \\
\text { adenocarcinoma }\end{array}$ & Mutations, steric hindrance \\
\hline Tivozanib & AV-951 & VEGFR1, 2, 3 & RCC, breast cancer & $\mathrm{ABC}$ transporters, $\mathrm{CSCs}$ \\
\hline Vatalanib & ND & VEGFR2 & $\begin{array}{l}\text { NSCLC, DLBCL, colorectal } \\
\text { adenocarcinoma }\end{array}$ & $\mathrm{CSCs}$ \\
\hline AZD8330 & ND & MEK1, 2 & Multiple myeloma & $\begin{array}{l}\text { BRAF amplification and new } \\
\text { BRAF V600E splice } \\
\text { isoforms, BRAF- } \\
\text { independent MAPK activa- } \\
\text { tion }\end{array}$ \\
\hline Binimetinib & ND & MEK1, 2 & Metastatic melanoma & $\begin{array}{l}\text { BRAF amplification and new } \\
\text { BRAF V600E splice } \\
\text { isoforms, BRAF- } \\
\text { independent MAPK activa- } \\
\text { tion }\end{array}$ \\
\hline Bosutinib & Bosulif/SKI-606 & SRC, BCR-ABL & $\mathrm{Ph}^{+} \mathrm{CML}$ & Mutation in targets \\
\hline
\end{tabular}


Table 2 (continued)

\begin{tabular}{|c|c|c|c|c|}
\hline Name & Trade name & Selective target & Resistant cancers & $\begin{array}{l}\text { Mechanism of resistance } \\
\text { (examples) }\end{array}$ \\
\hline Buparlisib & ND & $\mathrm{PI} 3 \mathrm{~K} \alpha, \beta, \delta, \gamma$ & $\begin{array}{l}\text { Multiple myeloma, head and } \\
\text { neck cancer, glioblastoma, } \\
\text { NSCLC }\end{array}$ & $\begin{array}{l}\text { Activation of compensatory } \\
\text { signaling pathways }\end{array}$ \\
\hline Cobimetinib & ND & MEK1, 2 & Metastatic melanoma & $\begin{array}{l}\text { BRAF amplification and new } \\
\text { BRAF V600E splice } \\
\text { isoforms, BRAF- } \\
\text { independent MAPK } \\
\text { activation }\end{array}$ \\
\hline Dasatinib & Sprycel & $\mathrm{ABL}, \mathrm{SRC}, \mathrm{cKIT}$ & $\mathrm{Ph}^{+} \mathrm{CML}$ and $\mathrm{ALL}$ & $\begin{array}{l}\text { Fixing the kinase domain in its } \\
\text { active configuration }\end{array}$ \\
\hline Defactinib & ND & FAK & $\begin{array}{l}\text { Malignant pleural } \\
\text { mesothelioma, NSCLC, } \\
\text { ovarian cancer }\end{array}$ & ND \\
\hline E6201 & ND & MEK1, 2 & $\begin{array}{l}\text { Melanoma, fallopian tube, } \\
\text { peritoneal cancer }\end{array}$ & $\begin{array}{l}\text { BRAF amplification and new } \\
\text { BRAF V600E splice } \\
\text { isoforms, BRAF- } \\
\text { independent MAPK } \\
\text { activation }\end{array}$ \\
\hline Entospletinib & ND & SYK & AML, CLL & ND \\
\hline Fostamatinib & ND & SYK, P-gp & T, B-cell lymphoma & ND \\
\hline GNF-5 & ND & BCR-ABL & $\mathrm{CML}$ & Mutation in target \\
\hline Ibrutinib & Imbruvica & BTK & $\begin{array}{l}\text { CLL, MCL, DLBCL, } \\
\text { multiple myeloma }\end{array}$ & Mutation in target \\
\hline Idelalisib & Zydelig & $\mathrm{PI} 3 \mathrm{~K} \delta$ & $\begin{array}{l}\text { CLL, indolent NHL, FL, } \\
\text { SLL }\end{array}$ & $\begin{array}{l}\text { Upregulation or activation of } \\
\text { other } \mathrm{PI} 3 \mathrm{~K} \text { isoforms }\end{array}$ \\
\hline Imatinib & Gleevec & $\mathrm{SRC}, \mathrm{BCR}-\mathrm{ABL}$ & ALL, CML, GIST & Mutation in target \\
\hline Lestaurtinib & CEP-701 & $\begin{array}{l}\text { JAK2, FLT3, TrkAC, } \\
\text { VEGFR2, PKC }\end{array}$ & AML & Mutation \\
\hline Momelotinib & ND & JAK1-2 & $\begin{array}{l}\text { Multiple myeloma, } \\
\text { metastatic pancreatic } \\
\text { ductal adenocarcinoma, } \\
\text { NSCLC }\end{array}$ & $\begin{array}{l}\text { Activation of compensatory } \\
\text { signaling pathways }\end{array}$ \\
\hline NSC 74859 & ND & STAT3 & Breast, prostate cancers & ND \\
\hline NVP-BYL719 & $\mathrm{ND}$ & $\mathrm{PI} 3 \mathrm{~K} \alpha$ & $\begin{array}{l}\text { Melanoma, head and neck } \\
\text { cancer }\end{array}$ & $\begin{array}{l}\text { Upregulation or activation of } \\
\text { other } \mathrm{PI} 3 \mathrm{~K} \text { isoforms }\end{array}$ \\
\hline OPB-51602 & ND & STAT3 & NHL, AML, ALL, CML & ND \\
\hline OPB-31121 & ND & STAT3 & $\begin{array}{l}\text { Multiple myeloma, Burkitt } \\
\text { lymphoma }\end{array}$ & ND \\
\hline P505-15 & ND & SYK & CLL & ND \\
\hline Pacritinib & ND & JAK2 & $\begin{array}{l}\text { AML, refractory CRC, } \\
\text { NSCLC, AML }\end{array}$ & ND \\
\hline PD0325901 & $\mathrm{ND}$ & MEK1, 2 & NSCLC, CRC, melanoma & $\begin{array}{l}\text { BRAF amplification and new } \\
\text { BRAF V600E splice } \\
\text { isoforms, BRAF- } \\
\text { independent MAPK } \\
\text { activation }\end{array}$ \\
\hline PF-00562271 & ND & FAK & NSCLC, ovarian cancer & ND \\
\hline Pictilisib & ND & $\mathrm{PI} 3 \mathrm{~K} \alpha, \delta$ & $\begin{array}{l}\text { Prostate, breast cancers, } \\
\text { NSCLC }\end{array}$ & $\begin{array}{l}\text { Upregulation or activation of } \\
\text { other PI3K isoforms }\end{array}$ \\
\hline Pilaralisib & ND & $\mathrm{PI} 3 \mathrm{~K} \alpha, \beta, \delta, \gamma$ & $\begin{array}{l}\text { Endometrial carcinoma, } \\
\text { breast cancer }\end{array}$ & $\begin{array}{l}\text { Activation of compensatory } \\
\text { signaling pathways }\end{array}$ \\
\hline Pimasertib & ND & MEK1, 2 & $\begin{array}{l}\text { Pancreatic, lung, ovarian } \\
\text { cancers }\end{array}$ & $\begin{array}{l}\text { BRAF amplification and new } \\
\text { BRAF V600E splice } \\
\text { isoforms, BRAF- } \\
\text { independent MAPK } \\
\text { activation }\end{array}$ \\
\hline Ponatinib & Iclusig, Ariad & BCR-ABL, SRC & $\begin{array}{l}\mathrm{Ph}^{+} \mathrm{CML} \text { and } \mathrm{ALL} \text {, hepatic } \\
\text { biliary, small cell lung and } \\
\text { thyroid cancers }\end{array}$ & Mutation in target \\
\hline Refametinib & $\mathrm{ND}$ & MEK1, 2 & Hepatocellular carcinoma & $\begin{array}{l}\text { Activation of compensatory } \\
\text { signaling pathways }\end{array}$ \\
\hline Ruxolitinib & Jakafi and Jakavi & JAK 1,2 & $\begin{array}{l}\text { Breast cancer, CML, AML, } \\
\text { NSCLC }\end{array}$ & $\begin{array}{l}\text { Activation of compensatory } \\
\text { signaling pathways }\end{array}$ \\
\hline Saracatinib & ND & SRC & & ND \\
\hline
\end{tabular}


Table 2 (continued)

\begin{tabular}{|c|c|c|c|c|}
\hline Name & Trade name & Selective target & Resistant cancers & $\begin{array}{l}\text { Mechanism of resistance } \\
\text { (examples) }\end{array}$ \\
\hline & & & $\begin{array}{l}\text { CRC, gastric, ovarian, small } \\
\text { cell lung and prostate } \\
\text { cancers, NSCLC }\end{array}$ & \\
\hline Selumetinib & ND & MEK1, 2 & $\begin{array}{l}\text { NSCLC, DLBCL, AML, } \\
\text { melanoma }\end{array}$ & $\begin{array}{l}\text { Activation of compensatory } \\
\text { signaling pathways }\end{array}$ \\
\hline Tofacitinib & Xeljanz, Jakvinus & JAK $1-3$ & Breast cancer & ND \\
\hline Trametinib & Mekinist & MEK1, 2 & $\begin{array}{l}\text { Melanoma, CRC, NSCLC, } \\
\text { gastrointestinal cancer }\end{array}$ & $\begin{array}{l}\text { Activation of compensatory } \\
\text { signaling pathways }\end{array}$ \\
\hline ABT-199 & Venetoclax & BCL-2 & CLL & $\begin{array}{l}\text { Mutations, impairment of } \\
\text { apoptosis }\end{array}$ \\
\hline Vemurafenib & Zelboraf & BRAF & $\begin{array}{l}\text { Melanoma, thyroid cancer, } \\
\text { CRC }\end{array}$ & $\begin{array}{l}\text { BRAF amplification and new } \\
\text { BRAF V600E splice } \\
\text { isoforms 2. BRAF- } \\
\text { independent MAPK } \\
\text { activation }\end{array}$ \\
\hline
\end{tabular}

HER human epidermal receptor, EGFR epidermal growth factor receptor, $N S C L C$ non-small cells lung carcinoma, $N D$ not defined, $V E G F R$ vascular endothelial growth factor receptor, $C S C s$ cancer stem cells, $P D G F R$ platelet-derived growth factor receptor, ABC ATP-binding cassette, FLT3 FMS-like tyrosine kinase 3, $A M L$ acute myeloid leukemia, $F G F R$ fibroblast growth factor receptor, $R C C$ renal cell carcinoma, $C M L$ chronic myeloid leukemia, $D L B C L$ diffused large B-cell lymphoma, $M A P K$ mitogen-activated protein kinase, $B C R$ B-cell receptor, $P I 3 K$ phosphatidylinositol 3-kinase, $A L L$ acute lymphoid leukemia, FAK focal adhesion kinase, $S Y K$ spleen tyrosine kinase, $C L L$ chronic lymphocytic leukemia, $B T K$ Bruton tyrosine kinase, $M C L$ mantle cell lymphoma, NHL non-Hodgkin's lymphoma, $F L$ follicular lymphoma, SLL small lymphocytic lymphoma, GIST gastrointestinal stromal tumors, JAK Janus kinase, $P K C$ protein kinase C, STAT signal transducers and activators of transcription, $C R C$ colorectal carcinoma, $P h+$ Philadelphia chromosome positive

Moreover, octamer-binding transcription factor (OCT) 4, SRY (sex determining region Y)-box (SOX) 2, kruppel-like factor (KLF) 4, and NANOG were highly expressed in $\mathrm{CD} 133^{+} /$ CXCR $4^{+}$OVCAR-5 cells, and these cells were determined to be resistant to cisplatin in transplanted nude mice. Moreover, primary ovarian cancer cells have been shown to overexpress the ATP-binding cassette (ABC) sub-family $G$ member (ABCG) 2 drug transporter protein, CXCR4 and CD133, and have been shown to have CSCs properties, including chemoresistance and tumor development [39].

It has been considered that embryonic stem cells (ESC) and CSCs have similar features, and it has been suggested that common molecules such as transcription factors may exist between ESCs and CSCs. SOX2 (SRY-related HMG-box gene 2) was originally described to be associated with the inhibition of neuronal cells differentiation and has been indicated to acts as an essential transcriptional factor to sustain the self-renewal ability of ESCs [40]. OCT4 (OCT3/4) is a member of the POU domain transcription factor family and has been shown to bind SOX2, which is the key regulator necessary for the self-renewal and pluripotency of ESCs [41].

NANGO transcription factor is another molecule that is expressed by CSCs and ESCs. It is a homeodomain protein that sustains the pluripotency of ESCs by preventing nuclear factor- $\mathrm{KB}(\mathrm{NF}-\mathrm{kB})$ and collaborating with signal transducer and activator of transcription (STAT) 3 transcription factor [42]. It has been indicated that downregulation of these transcription factors decreases the formation of tumor sphere and prevents tumor establishment in xenograft models [43]. In contrast, overexpression of these factors has been shown to be related with poor tumor prognosis and metastasis in different malignances, including gliomas, prostate and rectal cancers, gastric carcinoma, lung adenocarcinoma, and oral squamous cell carcinoma [44].

CD133 has been also described as a marker of tumorigenic cells in colon and brain tumors [20, 45, 46]. Although some studies have verified these results, however, other reports have suggested that this marker is not a common tumorigenic cells marker [47-49].

The OCT4 is expressed in aggressive human hepatocellular carcinoma and its expression associates with CSC markers [50]. Expression of SRY increased several stem cell factors, such as CD13 and OCT4. It has been shown that the promoter of OCT4 contained SRY-binding sites and was directly activated by SRY. In hepatocellular carcinoma cells, SRY knockdown reduced OCT4 expression and CSCs properties, such as chemoresistance, self-renewal, and tumorigenicity. However, overexpression of OCT4 and SRY has been noted to promote CSC phenotypes [50].

The expression of nestin (class VI intermediate filament) protein was initially detected in neural stem cells during ontogeny. Nestin expression has been reported in several tissues in pathological conditions [51]. It is overexpressed during the transformation of several human cancers, and the expression is correlated with disease progression. The expression of 
Initial tumor cells

Resistant tumor cells (e.g. CSC)

Mutated tumor cells (after 1st treatment)

Mutated tumor cells (after 2nd treatment)
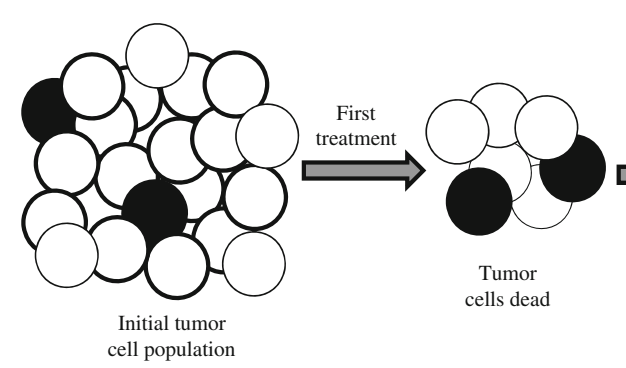

cell population

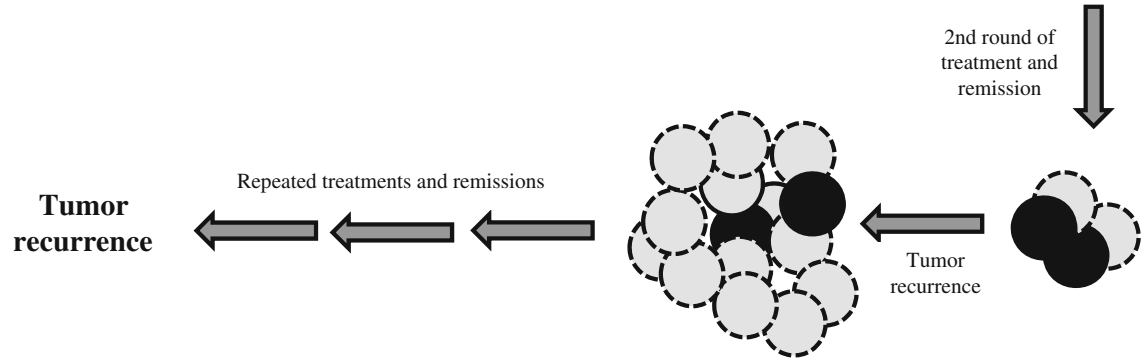

Fig. 1 Schematic cartoon showing the presence of several tumor cells populations. Each round of treatment destroys the sensitive cells; however, mutated cells due to the pressure of treatments as well as

nestin together with other CSC markers was described to be the phenotype of self-renewing cells in several cancers [51].

It has been shown that neural SCs and glioma SCs express similar markers. Glioma SC markers are nestin ${ }^{+}, \mathrm{CD} 15^{+}$, and $\mathrm{CD}_{133^{+}}$[52]. Nestin is expressed during brain development in glioma tissue. It is also expressed in $95.8 \%$ of glioma tumor cells and is correlated with disease prognosis. The expression of the nestin has been noted to be associated with poor disease prognosis in malignant pleural mesothelioma [53]. Therefore, it is mainly expressed in the invasive tumor cells that are located at the peripheral side of tumor rather than tumor center [54].

The surface receptor of hyaluronic acid, CD44, has been suggested as a CSC marker in gastric cancer. Its expression has been described to be associated with disease stage, tumor size, lymph node metastasis, venous invasion, and lymphatic invasion of gastric cancer cells [55].

Overall, while some studies have described similar stem cell phenotype for both normal and CSCs, however, other reports have suggested a few markers that differentiate CSCs from normal stem cells. More investigation is necessary to find specific surface or intracellular molecules (such as transcription factors) to differentiate CSCs from their normal counterparts.

On the other hand, current data strongly support the notion that CSCs might be considered as the major players of drug resistance, both to traditional chemotherapies and current targeted-therapy agents and the specific targeting of these cells might be a great step forward for cancer treatment. cancer stem cells (CSCs) survive and will start to grow in the proper time. CSCs are a minor population and are the main resistant population that will survive after treatments

\section{Expression of drug resistance proteins and changes in drug metabolism}

Drug metabolism is one of the main reasons for drug resistance. These factors include drug inactivation, absorption, distribution, and excretion. Tumor cell membrane and special membrane-bound proteins are responsible for drug efflux from the cells. Of several transporters, the $\mathrm{ABC}$ and the solute carrier (SLC) as well as xenobiotic metabolizing enzyme (XME) families are the most important transmembrane proteins that drive the transportation of many chemicals and drugs across the cell membrane [9]. Most of these proteins eliminate lipids from several kinds of hydrophobic drugs, including alkylating agents (cyclophosphamide, chlorambucil, lomustine, procarbazine), tyrosine kinase inhibitors (TKIs) (moceranib, masitinib, imatinib, genistein), platinum compounds (cisplatin, carboplatin), antimetabolites (gemcitabine, cytarabine, 5-fluorouracil, methotrexate), topoisomerase I and II inhibitors (camptothecins, indenoisoquinoline, mitoxantrone, doxorubicin), and microtubule inhibitors (vincristine, vinblastine, vinorelbine, paclitaxel) [9, 56, 57].

Different phases of drug metabolism in the body can change the efficacy of therapy on tumor cell growth. Several types of intracellular enzymes, such as the (glutathione-Stransferase(, (GST) family, cytochrome P450 (CYP) system, and uridine diphospho-glucuronosyltransferase (UGT) family are involved in drug metabolism inside the cells [58, 59]. 
Several tumor types or specific populations within a tumor overexpress specific glycoproteins in which they excrete drugs from the cells and in a way, they neutralize the effects of drugs [60,61].

As described, among different proteins, ABC, SLC, and $\mathrm{XME}$ molecules are the major types of drug transporters that induce drug resistance. $\mathrm{ABC}$ transporters are divided into three subtypes, including importers, exporters, and those which are involved in DNA repair and translocation process [62, 63].

Currently, more than 49 genes have been detected to encode the members of $\mathrm{ABC}$ transporter family, which are categorized into 7 sub-families (A to G). Several studies have described the effects of gene polymorphisms on drug transporters [64] and in $\mathrm{ABC}$ transporter family, more than 50 SNPs have been detected [65]. ABC sub-family B member 1 (ABCB1) and sub-family G member 2 (ABCG2), Pglycoprotein $(\mathrm{P}-\mathrm{gp})$, breast cancer resistance protein (BCRP), multidrug resistance protein 1 (MDR1), and multidrug resistance-associated protein 1 (MRP1) are among the most involved proteins in drug resistance [64]. Polymorphisms may change clinical outcomes through several mechanisms. The effectiveness of ABCB1 or ABCG2 function may increase through the decrease of binding to SMIs. Moreover, transporters with dysfunctions may result in increased toxicity due to changed transport of drugs from normal cells such as bone marrow cells. It has been shown that synonymous SNPs in the ABCB1 change the reaction of the drug with the transporter, due to changes in protein folding [63].

SLC transporter system has 52 families and 362 different genes [66]. Three families are the major players for cancer drug efflux, including the organic anion transporting family the SLC21 (SLCO), the SLC22 (the organic cation/anion/ zwitterion transporter family), and the SLC15 (the proton oligopeptide cotransporter family).

XME enzymes are another family of enzymes involved in biotransformation of anti-cancer drugs [60]. Cytochrome P-450 isoform families (18 families with 57 different isozymes), UDP glucuronosyltransferase families (2 families with 16 isozymes) [67], and glutathione S-transferases (6 families with 16 isozymes) [68] are among the most prominent families. Other members of this big family are aldo-keto reductases [69], short chain dehydrogenase or reductase [70], carbonylreductase [71], alcohol dehydrogenase [72], aldehyde dehydrogenase [73], xanthine/aldehyde oxidase [74], nicotinamide adenine dinucleotide phosphate (NADPH)-quinone oxidoreductase [], flavin-containing monooxygenase [75], sulfotransferase [76], arylamine $\mathrm{N}$-acetyltransferase [], and epoxide hydrolase [77]. Activation of these proteins induces drug resistance in tumor cells.
Due to the high number of the members in ABC, SLC, and XME enzymes, these enzymes can specifically be involved in the metabolism and inactivation of a broad range of cancer drugs. For example, resistance to methotrexate in various leukemias has been shown to be due to the decreased influx of this drug that is mediated by the SLC19A1 enzyme, a member of SLC family. Several genetic alterations such as point mutations led to downregulation of SLC19A1 protein expression and decreased the influx of anti-cancer drugs [61].

\section{Extracellular vesicles and drug resistance}

Extracellular vesicles (EVs) (such as exosomes and microvesicles) are known as small particles (100-1000 nm) that are surrounded by phospholipid bilayer similar to the cell membrane. These vehicles are important organelles, involved in various intercellular transportations (Fig. 2) [78]. One of the major roles of these microvesicles is disseminating cancer drug resistance to other non-resistant cancer cells. Specifically, these organelles transfer different molecules involved in resistance to other cells by shedding from resistant cells and consequently induce drug resistance to non-resistant cells. Several mediators, such as microRNAs (miRNAs) (miR-100, miR-222, miR-30a, miR-34a, miR-145, miR-4853p, miR-1228, miR-1246, miR-1308, miR-149, miR-455-3p, miR-638, miR-923, miR-1246, miR-23a, miR-1469, miR638, miR-1915, miR-2861) and drug efflux pumps (P-gp, ABCG2, MRP1, ABCA3) are transported by these exosomes or microvesicles and when they reached the recipient nonresistant cell, they are fused and internalized by cells via endocytic pathway [78].

In addition to the transfer of drug-resistant phenotype to non-resistant cells, these organelles are directly involved in the removal of cancer drugs from treated cells $[79,80]$.

For example, doxorubicin and several SMIs have been collected in these vesicles and are shed by tumor cells after treatment [79]. It is suggested that the hydrophobic characteristics of some drugs may enhance their interaction with lipid layer of vesicles and finally result in drug elimination from the cells. Moreover, the presence of several drug transporters in these vesicles, such as ATP7A/B and MRP2, increases the efflux of drugs from cancer cells $[78,80]$. The presence of drugresistant proteins has been shown in several malignancies, such as P-gp in docetaxel-resistant prostate cancer cells [81] and paclitaxel-resistant ovarian cancer cell line [82], MRP1 transporter in ALL [83], ABCG2 in doxorubicin-resistant breast cancer cells [84], and ABCA3 in rituximab-resistant B-cell lymphoma cells [85], which are responsible for induction of drug resistance in these tumors [78]. 


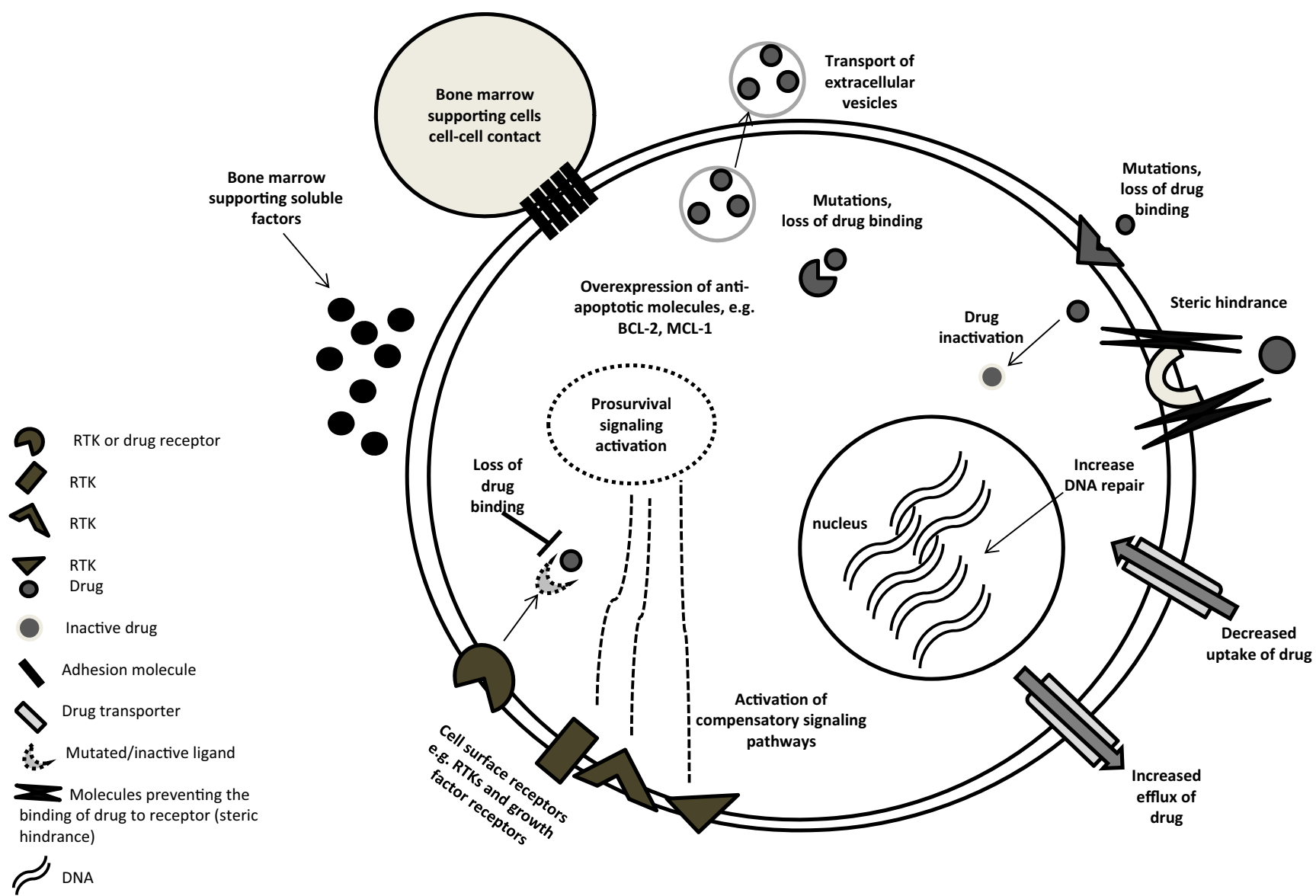

Fig. 2 A summary of various mechanisms of anti-cancer drug resistance. Mutations in drug target, activation of compensatory signaling pathways, increase in DNA repair system, and overexpression of anti-apoptotic proteins are the major mechanisms of resistance

\section{Modified expression of target protein}

Several studies have noted the development of resistance to cancer drugs due to over or low expression of target proteins [86].

Post-treatment overexpression of the androgen receptor gene has been described in around $30 \%$ of recurrent prostate cancer patients that were treated by castration; however, untreated prostate cancer patients did not show amplification of androgen receptor [87].

It has been shown that the activity of B-cell receptor (BCR)-ABL is required for development and transformation of CML. Various inhibitors have been produced to target BCR-ABL oncoprotein and have been tested in clinical trials (herbimycin A and 2-phenylaminopyrimidine ST1571). However, later researches showed the development of drug resistance due to overexpression of BCR-ABL oncoprotein [86].

Overexpression of IGF-1R has been shown to reduce the inhibitory effects of trastuzumab on human epidermal receptor (HER) 2-overexpressing breast cancer cells and induce resistance of tumor cells to trastuzumab [88]. Blocking IGF-1 by
IGF-binding protein 3 (that inhibits the activation of IGF-1R) restored the sensitivity of tumor cells to trastuzumab.

Moreover, in patients with lung cancer, amplification of MET oncogene is one of the main mechanisms that lead to acquired resistance to gefitinib and erlotinib [89].

Data show that decrease or increase expression of target proteins by tumor cells, in several cases is associated with tumor cells resistance, especially to targeted-therapy agents.

\section{Dysregulation of apoptosis}

Various cancer drugs may induce DNA impairment and induce apoptosis and necrosis of tumor cells following the activation of the downstream apoptosis pathways (Fig. 2). However, apoptosis deregulation of tumor cells has been ascribed as a major hallmark of cancer cells that failed the effects of chemotherapeutic and targeted-therapy agents [90]. The anti-apoptotic property of tumor cells is usually based on the dysregulation (usually overexpression) of a few genes, such as B-cell lymphoma (BCL)-2, myeloid cell leukemia (MCL)-1, and tumor necrosis factor (TNF)-related apoptosis-inducing ligand (TRAIL). Overexpression of the anti-apoptotic BCL- 
2 protein has been shown to prevent mitochondria-associated apoptosis pathway and prompts resistance to cancer agents [91, 92]. Therefore, targeting upregulated molecules by TBCT agents such as SMIs is an interesting approach to sensitize tumor cells to targeted therapies (e.g., in combination with other treatments). Targeting BCL-2 by SMIs is under intensive investigation, and currently, FDA is evaluating BCL-2 SMI, venetoclax (RG7601, GDC-0199/ABT-199) for the treatment of relapsed or refractory chronic lymphocytic leukemia (CLL) patients with $17 \mathrm{p}$ deletion.

TRAIL molecule has been known as an important factor in apoptosis pathway and behaves as a ligand that induces the process of apoptosis. Downregulation of TRAIL has been shown to be associated with drug resistance in several malignancies and to overcome drug resistance, induction of TRAIL expression is a proper strategy [93-95]. Currently, three therapeutic strategies have been described for activation of TRAIL pathway, including the administration of TRAIL (recombinant form) (known as Apo2L/AMG951), using activating human anti-death receptor 4 (mapatumumab) or DR5 (lexatumumab) antibodies and delivery of the TRAIL coding sequence in adenoviral (Ad) format into cancer cells (Ad5TRAIL). These methods are under investigation for inducing apoptosis in tumor cells $[56,96]$.

Current data on targeting and activating apoptosis-inducing proteins in tumor cells with dysregulated apoptotic proteins are useful, and the combination of these agents with other cytotoxic agents are promising and might confer a higher survival rate for cancer patients.

\section{Repair of DNA damage}

DNA damage repair is another mechanism that contributes to induction of cancer drug resistance (Fig. 2). Many chemotherapeutic agents, such as platinum drugs, topoisomerase inhibitors, and alkylating agents, induce DNA damage; however, DNA damage repair machinery of tumor cells effectively influences the effects of DNA-damaging drugs [13].

A proper therapeutic approach is to inhibit DNA damage repair system of malignant cells and thus different agents that inhibit components of the DNA repair machinery have been developed [14]. The most noticeable example of targeting DNA damage repair is inhibitors of the DNA repair enzyme poly-ADP-ribose polymerase (PARP). Several PARP inhibitors have been produced and have shown promising effects. Olaparib induces cell death in cancer cells with mutations in the BRCA1 (breast cancer 1) and BRCA2 (breast cancer 2) tumor suppressor genes. These genes are crucial for repair of DNA double-strand breaks (homologous recombination). Lack of repair of DNA double-strand breaks is usually compensated by single-strand repair mechanisms that are dependent on the function of PARP. Therefore, PARP inhibition induces cell death due to the genetic instability in dividing tumor cells [56].

The same as targeting anti-apoptosis proteins, the combination of drugs that target DNA repair machinery of tumor cells with other cytotoxic agents may be useful to prevent anticancer drug resistance.

\section{Bone marrow microenvironment and drug resistance}

Tumor cells located in bone marrow are usually more resistant to cancer drugs than cells in peripheral blood (Fig. 2). Several studies have described that the protection is afforded by secreted chemokines and expression of their ligands, such as CXCL12 and CXCR4 in bone marrow environment and by stromal cells that support tumor cells through cell to cell contacts with tumor cells [97, 98] (Fig. 2).

For instance, inhibition of FMS-like tyrosine kinase-3 (FLT3) by inhibitors (e.g., FI-700) has shown good clinical results in AML patients with FLT3 mutations; however, the bone marrow tumor cell responses are frequently less than the peripheral blood tumor cells. It has been shown by Kojima et al. that protection is mediated via CXCL12/CXCR4 signaling in the bone marrow [99].

To overcome the resistance of AML cells (with FLT3mutations) to SMIs, a combination of different types of SMIs such as JAK inhibitors with FLT3 inhibitors has been shown to override the effects of bone marrow stromal cellmediated resistance of AML cells [100].

In addition to bone marrow microenvironment, other factors such as cytokine/chemokine milieu might affect the sensitivity of tumor cells to drugs. For example, exposure to platinum doublets (cisplatin plus vinorelbine) has been described to change the cytokine/chemokine microenvironment and the phenotype of lung tumor cells, rendering them more sensitive to cytotoxic T lymphocyte (CTL)-mediated lysis [101]. It has been noted that exposure to platinum doublets significantly reduced the protein secretion ratio of transforming growth factor- $\beta$ (TGF- $\beta$ ) to interleukin (IL)- 8 . Moreover, gene expression studies of two lung tumor cells in response to sublethal chemotherapy has shown the expression of 16 genes, including those related to cytokine/chemokine and apoptotic proteins as tumor necrosis factor- $\alpha$ (TNF- $\alpha$ ), CXCL5, IL-8, and B-cell lymphoma-2 (BCL-2) genes. These data may indicate that sublethal doses of cisplatin/vinorelbine enhances the sensitivity of tumor cells to perforin/granzyme-mediated CTL killing thought modulation of tumor cells phenotype, cytokine/chemokine milieu, and the ratio of pro-apoptotic to anti-apoptotic proteins [101].

\section{Steric hindrance and drug resistance}

Steric hindrance is another mechanism of drug resistance. It is demonstrated that overexpression of other molecules that 
surround the target protein inhibits the interaction of cancer drugs with targeted protein [102]. For example, resistance of tumor cells to trastuzumab has been described to be related to high expression of MUC4 (a membrane-associated glycoprotein) in HER2-overexpressing cells. MUC4 has been shown to bind to HER2 and inhibits binding of trastuzumab to HER2 through steric hindrance [103]. It is suggested that MUC4 may be associated with cancer development due to the ability to inhibit the recognition of tumor cells by the immune system and prompt the metastasis and progression of cancer cells via activation of HER2 and prevention of tumor cell apoptosis [104]. Moreover, the mucinous subunit of MUC4 (ASGP-2) binds to HER2 through the EGF-like region of HER2 [103]. It has been proposed that MUC4 may increase the phosphorylation of HER 2 on tyrosine residue 1248 [103], which increase the transforming ability of HER2 [105]. Decreasing the expression of MUC4 gene has been shown to increase the effects of trastuzumab on MUC4 knockdown cells [106]. It is suggested that MUC4 might hide epitopes of HER2 that bind to trastuzumab and inhibits the binding of HER 2 to antibody and prevents the heterodimerization of HER2 with other epithelial growth factor receptor (EGFR) members, such as HER3 and EGFR, via steric hindrance that results in resistance of cells to drug [106].

Therefore, downregulation or blocking the expression of molecules involved in steric hindrance might be considered as a proper strategy to overcome this type of resistance in tumor cells.

\section{Acquired resistance}

Several factors, including tumor cell heterogeneity, changes in drug targets, mutations after treatments, hyperactivation of prosurvival signaling pathways, up/downregulation of specific microRNAs, crosstalk between survival signaling pathways, and chronopharmacology factors contribute to the development of acquired resistance following tumor treatments (Table 1, Figs. 1 and 2).

\section{Tumor cell heterogeneity after treatment}

As described in natural resistance factors, a tumor is typically originated from a normal or non-cancerous cell, which undergoes through several processes that are called tumorigenic transformation. This transition is the result of different mutations in the genome, which converted the origin normal cell to an unusual tumor cell. Moreover, an established tumor is persistent by several subpopulations of cells that are selfrenewing (CSC) and can generate tumorigenic cells [107, 108]. The heterogeneity of tumor cells has been described in natural resistance section.

\section{Changes in drug target in tumor cells: methylation and mutations}

Qualitative and quantitative modifications in drug targets are critical mechanisms of drug resistance. These changes may be quantitative, such as reduced or lost the expression of the drug target, or may be induced by factors as inhibition of drug binding to the targets by other proteins. These changes contribute to both natural and acquired resistance. Induction of mutation that modifies the structure of drug targets (genetic alteration) is a qualitative factor that may change the affinity of the drugs for their targets. Several types of these mutations have been described in next section.

In addition to genetic alterations, other factors such as epigenetic factors might contribute to drug resistance. Epigenetic modifications usually change the expression of target genes. These alterations mostly comprise of covalent modifications of DNA sequence and histone modifications that change gene expression levels by methylation of gene promoter (at cytosine residues by methyltransferase enzymes in the $\mathrm{CpG}$ islands of gene promoter regions) or indirectly by changes in chromatin packaging that regulate the availability of DNA to special transcription factors. These modifications that induce drug resistance are associated with dysregulation of apoptotic factors and DNA repair enzymes as well as abnormal expression of drug efflux transporters [56].

Several studies have shown the association of these changes with drug resistance. In DU145 prostate cancer cells, docetaxel and cabaxitaxel resistance (DU145 10DRCR) has been described to be associated with DNA methylation of cell-cycle regulatory and pro-apoptotic genes [109]. Hypermethylation of $\mathrm{CpG}$ island that silences DNA/RNA helicase Schlafen-11 (SLFN11) enzyme has been noted to be related to resistance to chemotherapeutic agents such as platinum compounds [110]. Inhibition of DNA methylation using methylation inhibitor decitabine (5-aza-2'-deoxycytidine or DAC) has been shown to sensitize AML cells to the chemotherapy agent. Decitabine is a DNA hypomethylating agent and induces differentiation and apoptosis of AML leukemic cells to aclacinomycin (ACLA) and cytarabine. Decitabine has described to decrease the expression of DNA methyltransferase 1 (DNMT1) in AML patients [111].

Several types of acquired mutations have been described during the treatment of malignancies (Table 2).

Point mutations are very common and occur in dividing tumor cells and are the most frequent mechanism of acquired TKI resistance [112-114]. The most frequent type of point mutations reduces the affinity of the target for the drug while the enzyme catalytic activity may not change. The changes in the amino acids near the enzyme binding site for the drug are another type of mutations and reduce the accessibility of the target region for the inhibitor binding [115]. Other point mutations increase the affinity of the enzyme for ATP and 
decrease the effectiveness of the type I inhibitors (ATP competitors) (Tables 1 and 2).

The best example of acquired resistance, due to mutations, is CML patients, resistant to imatinib TKI that targets BCL$\mathrm{ABL}$ oncoprotein. CML patients constitutively express active BCR-ABL. Imatinib prevents the activity of BCR-ABL by binding to the inactive protein and inhibits autophosphorylation and activation of downstream signaling proteins [116]. However, the majority of patients in advanced or chronic stages develop imatinib resistance [117]. More than $30 \%$ of the relapsed CML patients gain point mutations that are near 100 different point mutations. These mutations change the 3dimensional structure of the ABL kinase and abrogate the ability of the imatinib to bind the ABL kinase [116, 118]. To target the ABL mutants in imatinib-resistant patients, the second generation of TKIs, such as nilotinib, dasatinib, bosutinib, and sunitinib, were developed $[119,120]$. These TKIs recognize a distinct conformation of BCR-ABL and are proper for imatinib-resistant patients. Dasatinib and nilotinib interact with several mutants of ABL (imatinib-resistant); however, these SMIs are not suitable for T315I (threonine to isoleucine substitution at position 315) mutant form that modifies the kinase and different contact points between the SMIs and the protein kinase [121]. KW-2449 inhibitor has been developed to inhibit T315I mutant form [122].

As a multi-targeted TKI, imatinib binds to the cKIT and platelet-derived growth factor receptor (PDGFR). The kinase is highly active in gastrointestinal stromal tumors (GIST) [123]. However, the same as AML patients, more than $50 \%$ of GIST patients have been noted to develop mutation within KIT gene that confers decreased affinity of imatinib to the kinase [124]. To inhibit the activity of the mutants cKIT, sunitinib was produced; however, imatinib-resistant GIST patients developed resistance to this TKI [125].

Activating FLT3 mutations frequently happen in AML. Treatment of AML patients with PKC412 (staurosporine derivative) prevent FLT3 activity; however, several patients developed mutations in the FLT3 kinase region [126].

As previously described, sorafenib (multi-kinase inhibitor) targets vascular endothelial growth factor receptor (VEGFR) 1-2, BRAF, PDGFR, cKIT, and FLT3 [4]. This TKI has shown broad anti-tumoral activity. The combination of sorafenib with other TKIs has induced a variety of point mutations in FLT3 [127], PDGFR [128], and BRAF [129] that confer tumor resistance.

For the treatment of breast cancer patients, lapatinib is a proper TKI and is approved by the FDA as an EGFR inhibitor. It has been developed to suppress phosphorylation and downstream signaling of EGFR and HER2 [130]. Twelve mutations in the kinase region of HER2 have been shown to confer resistance to lapatinib [131]. In contrast to lapatinib, EXEL-7647 is active on all mutant forms.
Other EGFR-TKIs, such as erlotinib and gefitinib, are among the most widely investigated SMIs in NSCLC and were approved by the FDA for the treatment of this cancer. These SMIs are ATP-competitor TKIs and belong to the first generation of selective EGFR-TKIs [4]. These TKIs are used as the front-line targeted therapy for NSCLC patients with EGFR mutations. However, the efficacy of these TKIs is shown to be impeded by different mutations of EGFR members. Mutations that activate the EGFR members, as the deletion in exon 19 and L858R (leucine to arginine substitution at position 858) point mutation, are the most frequent mutations, and patients show good response to these two TKIs that increase the kinase activity of EGFR members [3, 4]. However, T790M missense mutation and insertions in exon 20 are early genetic events that confer resistance to EGFR-TKIs in NSCLCs. It has been shown that T790M-EGFR point mutation increases steric hindrance at the ATP-binding region of EGFR and inhibits the binding of EGFR-TKIs such as gefitinib to EGFR members [3, 4].

Afatinib (irreversible EGFR-TKI) is useful in combination with cetuximab (anti-EGFR mAb) on T790M-EGFR mutants which can overcome acquired resistance induced by reversible EGFR-TKIs. Afatinib plus cetuximab has been indicated to induce significant regression in erlotinib-resistant NSCLC cells with T790M in vitro. Moreover, the combination of afatinib (40 mg/day) plus cetuximab $\left(500 \mathrm{mg} / \mathrm{m}^{2}\right.$ every 14 days) has shown good effects in a cohort of 22 NSCLC patients with acquired resistance to gefitinib and erlotinib [132]. In a phase I and II cohorts, 100 pretreated EGFRmutant patients were treated with afatinib in combination with cetuximab. Data showed 38 and $47 \%$ overall response rate (ORR) in T790M mutation positive- and negative-treated patients, respectively, as well as 4.6 months of median progression-free survival (PFS) in spite of confirmed T790M. Currently, other trials, such as ECOG and SWOG, are testing the efficacy of afatinib with or without cetuximab as salvage or first-line treatment for EGFR-mutant patients [133].

Several point mutations in HER2, such as V777L (valine to leucine substitution at position 777), L866M (leucine to methionine substitution at position 866), V842I (valine to isoleucine substitution at position 842), L755S (leucine to serine substitution at position 755), G309A/E (glycine to alanine/ glutamic acid substitution at position 309), and S310F (serine to phenylalanine substitution at position 310), have been described in colon and breast cancer cells. These mutations have shown to increase the activity of signaling pathways and cell growth. Several studies have noted that these activating mutations induced resistance to anti-EGFR treatments, such as cetuximab and panitumumab, by increasing mitogenactivated protein kinases (MAPK)/ERK phosphorylation. However, neratinib and afatinib (irreversible EGFR-TKIs) inhibit HER2 mutants in low nanomolar doses [134]. 
Crizotinib, an ALK-TKI, has showed high efficacy in a subgroup of NSCLC patients with EML4-anaplastic lymphoma kinase (ALK) gene rearrangement [135]. However, most of these patients have developed acquired resistance to crizotinib in 1 to 2 years after treatment. Several mechanisms have been described to be responsible for acquired resistance to criztinib. Alteration of the EGFR gene, EGFR-T790M mutation, $A L K$ gene mutations, such as F1174L (phenylalanine to leucine substitution at position 1174), L1196M (leucine to methionine substitution at position 1196), G1202R (glycine to arginine substitution at position 1202), C1156Y (cysteineto-tyrosine substitution at position 1156), G1269A (glycine to alanine substitution at position 1269), and S1206Y (serine to tyrosine substitution at position 1206), are the main mutations. Other mechanisms are bypass intracellular signaling pathway via fibroblast growth factor receptor-1 (FGFR1), AXL, and MET overexpression [136]. Alectinib (a selective ALK-TKI) has been used for the treatment of crizotinib-resistant patients; however, several treated patients have developed acquired resistance due to two novel ALK mutations (V1180L/valine to leucine substitution at position 1180 and I1171T/isoleucine to threonine substitution at position 1171) [137].

Ibrutinib is a TKI of Bruton tyrosine kinase (BTK) that binds covalently to cysteine 481 . This inhibits the SYK and LYN autophosphorylation of the SRC homology (SH) 3 domain and prevents downstream activation of BCR signaling and phospholipase $\mathrm{C} \gamma 2$ (PLC $\gamma 2$ ). However, acquired ibrutinib resistance due to mutations in BTK and PLC $\gamma 2$ has been described [138]. Recently, a cysteine-to-serine mutation in BTK (C481S) has been shown that converts ibrutinib covalent binding to reversible binding with the lower effect of ibrutinib [138]. Moreover, two mutations in PLC $\gamma 2$ (R665W/ arginine to tryptophan substitution at position 665 and L845F/ leucine to phenylalanine substitution at position 845) that are gain-of-function mutations have been described to be involved in ibrutinib resistance in CLL patients $[138,139]$.

Recently, Acalabrutinib or ACP-196 that is an irreversible BTK inhibitor with more selectivity has been designed to decrease the side effects of first-generation BTK inhibitors [140]. The anti-tumor impact of this inhibitor has not been tested in ibrutinib-resistant patients.

\section{Hyperactivation of prosurvival signaling pathways}

Hyperactivation of intracellular signaling pathways is an important mechanism of cancer drug resistance. Several pathways including phosphatidylinositol-4,5-bisphosphate 3kinase $(\mathrm{PI} 3 \mathrm{~K}) / \mathrm{AKT} / \mathrm{mammalian}$ target of rapamycin (mTOR), ERK/MEK, NOTCH, WNT, forkhead box O3 (FOXO3) A, and STAT pathway hyperactivation have been described for several tumors, such as AML and multiple myeloma [141-147].
It has been noted that the inhibition of FLT3 by TKIs would not inhibit the downstream signaling molecules, such as AKT, ERK, S6K, and STAT in sorafenib-resistant AML cells with mutations in the tyrosine kinase domain of the FLT3 [142]. In these cells, it has been described that activation of MEK/ERK or PI3K/AKT pathways in resistant cell lines is the main reason for tolerance to sorafenib. Blocking MEK, AKT, and mTOR by SMIs induced apoptosis of resistant cells to sorafenib [142, 148].

In breast cancer, it has been demonstrated that overexpression of glutathione and activation of WNT signaling pathway are the main reasons for radio-resistance of tumor cells [149]. The synergistic effects of entinostat/lapatinib combination were described to overcome cancer resistance to lapatinib in HER2-overexpressing tumor cells. The promising effects were due to downregulation of $\mathrm{AKT} / \mathrm{FOXO} 3$ pathway that results in activation of Bim1 (pro-apoptotic protein) [148].

Hyperactivation of NOTCH signaling pathway has been described in breast CSCs. Inhibition of NOTCH signaling has been shown to increase the sensitivity of the cells to cancer drugs [149].

Hyperactivation of other signaling molecules as STAT3 and NF-KB in glioblastoma [141] and WNT/ $\beta$-catenin signaling pathway have been described in different cancers that are resistant to cancer drugs $[143,144,150]$.

\section{MicroRNAs and acquired cancer drugs resistance}

miRNAs/miRs are non-coding, single-stranded RNAs that contain 19-22 nucleotides. These short RNAs behave as regulators of signaling pathways and are important key regulators in tumor progression [151].

Several studies have shown links between the altered expression of miRNAs and acquisition of drug resistance [152]. MiRNA deregulation in cancers has been indicated to be involved in defective miRNA biogenesis pathways, deregulation of gene transcription, epigenetic modifications, such as methylation of the $\mathrm{CpG}$ islands, induction of mutations, and alteration of DNA copy numbers. One or more factors may contribute to miRNA deregulation in human cancer [153]. These molecules have dual function in cancer drug resistance and overexpression, or downregulation is associated with both sensitivity and resistance to cancer therapeutic drugs.

Drug resistance due to miRNA expression has been described for several malignancies. miR-7, miR-10, miR-15a, and miR-16 have been described to target MDR1, homeobox D10 (HOXD10), BCL-2, and cyclin-D1 (CCND1) genes, respectively, and induce resistance to cisplatin, taxol, tamoxifen, and docetaxel in breast cancer [151]. Altered expression of miRNA has been noted to induce chemotherapy resistance by targeting vital signaling molecules, such as phosphatase and tensin homolog (PTEN) and estrogen receptor (ESR) 1 in AKT, K-RAS and MAPK in PI3K/AKT signaling 
pathways, and BCL-6 and BCL-2 molecules. Moreover, MDR1 protein, which is involved in drug resistance, has been indicated to be deregulated by the expression of miRNAs. Also, modification of the levels of miRNAs that target zinc finger E-box-binding homeobox (ZEB) 1 and C-MYC molecules (involved in epithelial mesenchymal transition; EMT) have been noted in resistance of breast cancer cells to chemotherapies.

Overexpression of miR-210 was described to be related to the sensitivity of breast cancer cells to trastuzumab in patients with the minimal residual disease compared to patients that have a complete response and in patients with metastasis of tumor cells to lymph nodes [154].

Expression of miR-34a has been indicated to sensitize gefitinib-resistant NSCLC and HCC 827 cell lines [155].

Microarray studies demonstrated that chronic exposure of A549 cell line with gefitinib increases the expression of 25 miRNAs and suppresses the expression of 18 others. This difference in the expression of miRNAs has been noted to be related to a 3 -fold increase in IC50 of gefitinib. In this study, the expression of miR-7 has been observed to abolish the overexpression of EGFR and restored the sensitivity of A549 cells to gefitinib [156].

Overall, current studies strongly suggest the critical role of miRNA expression in cancer drug resistance. While some miRNA expression is associated with drug resistance, the expression of several others has been shown to be associated with sensitivity of tumor cells to cancer drugs. Currently, several studies are investigating the role of miRNAs in cancer drug resistance.

\section{Crosstalk between intracellular signaling pathways}

Crosstalk between several intracellular signaling pathways is one of the major reasons for acquired resistance to targetedtherapy agents [139]. BCR and receptor tyrosine kinase-like orphan receptor 1 (ROR1) [157-163] signaling pathway cross-communication is an example that has been recently reported [164]. It has been noted that BCR and ROR1 control each other expression in a manner that is vital for tumor cell survival in ALL patients [164]. Downregulation of BCR by the BCR-ABL TKI dasatinib (inhibits the Philadelphia chromosome), as well as inactivation of AKT, inhibition of $\operatorname{Ig} \alpha$ and $\operatorname{Ig} \beta$, induced upregulation of ROR 1 in leukemic cells. On the other hand, downregulation of both ROR1 and BCR dephosphorylated AKT prevented cell growth and increased cell killing. However, downregulation of ROR1 or BCR did not induce the same effects, suggesting complementary effects. The data also indicated an intracellular link (PI3K/AKT) between the BCR and ROR1 signaling pathways [139, 164].

Crosstalk between RTKs, such as EGFR family members, insulin-like growth factor-I receptor (IGF-1R), VEGFR, and MET, are known to enhance cancer progression and induction of drug resistance [165]. The anti-HER2 mAb trastuzumab has improved outcomes in HER2-positive breast cancer patients. However, many patients develop resistance within the first year of treatment [166]. Activation of multiple-receptor tyrosine kinase (RTK) signaling pathways has been indicated to contribute to trastuzumab resistance. Similarly, a considerable percentage of lung or colon cancer patients do not respond to anti-EGFR treatments and acquired resistance after primary treatments [167].

Resistance of HER2-overexpressing tumors to trastuzumab has been shown to be associated with signaling from IGF-1R in breast cancer. Crosstalk between IGF-1R and HER2 through physical interaction of IGF1R with phosphorylates HER2 induced acquired resistance in trastuzumab-resistant cells; however, this interaction does not happen in trastuzumab-sensitive tumor cells [102].

Alectinib is a selective ALK-TKI, and several studies have indicated promising efficacy in NSCLC with EML4-ALK gene rearrangement. However, several treated patients have shown acquired resistance to this second generation of ALK-TKI [137]. In addition to point mutations, other mechanisms have been described for acquired resistance. By using alectinib-resistant H3122 NSCLC cell line (H3122-AR) with the EML4-ALK gene rearrangement, it has been described that there is increased phosphorylation level of EGFR in H3122-AR cells compared with H3122 [137]. Increased secretion of transforming growth factor (TGF) $\alpha$ (EGFR ligand) has been shown to be the reason for the hyperactivation of EGFR. Blocking TGF $\alpha$ expression has been indicated to restore the sensitivity of H3122-AR cells to alectinib. Dual targeting of ALK and EGFR by alectinib and afatinib has showed to restore the sensitivity of H3122-AR cells to treatment both in vitro and in a mouse xenograft model [137].

Overall, the complication of tumor cells signaling suggests the requirement of targeting several RTKs for efficient cancer therapeutics.

\section{Chronopharmacology and resistance to targeted therapies}

Chronopharmacology is the study of the effects and behavior of therapeutic agents during the biological timing and endogenous factors. The goal of chronopharmacology is to increase the understanding of periodic and predictable changes in the effects and tolerance of drugs in tumor patients (in the field of tumor treatment) $[168,169]$. Several studies have described that anti-tumor effect of cancer drugs differs at the time of day of administration, and it might be a clinically important factor in cancer-treated patients that may prevent drug resistance [170].

The impacts of timing on the anti-tumor effects of erlotinib have been investigated in the mouse model of Lewis lung cancer xenografts [170]. Results proposed that anti-tumor efficacy and toxicity of erlotinib on xenografts of NSCLC mice model is 
dependent on the time of day of administration. The effects may be associated with the EGFR-AKT/cyclin D1/cyclin-dependent kinase (CDK) 4 signaling pathway and might be a clinically important variable [170]. The association of chronopharmacology factors with cancer drug resistance has not been well studied, and more investigations are necessary to explore the effects for prevention of drug resistance.

\section{Conclusions and future prospective}

Current data indicate that most or all patients with cancer develop resistance to different types of treatments, including chemotherapy and targeted-therapy regimens. The resistance to cancer drugs is due to the combination of several complicated factors, including pharmacokinetic and pharmacodynamic mechanisms. These factors that are involved in drug resistance might be due to primary reasons that developed in the absence of drugs or are secondary due to the drug effects. Therefore, a better understanding of tumor cell biology and mechanism of tumor cell resistance to therapies is necessary to define proper strategies and avoid drug resistance. To prevent drug resistance, several strategies, such as targeting various molecules that are expressed by tumors (multiple-targeted therapy) using SMIs and mAbs and combination therapy, such as SMI combination with immunotherapy methods, and targeting CSCs or optimizing the methods of intra-tumoral drug delivery as well as a defined treatment guideline for each cancer, might be necessary to prevent drug resistance and cancer recurrence. CSCs are highly resistant to cancer drugs and very likely cause disease relapse. Specific targeting of these cells is a major obstacle to cancer treatment. Overwhelming this problem in different cancers is important; however, difficultto-achieve. Moreover, a better understanding of bone marrow microenvironment, mechanisms of overactivation of survival signaling pathways by tumor cells and CSCs, and cell-to-cell interaction of tumor cells with supporting cells are important factors for defeating cancer. On the other hand, current drugs might not be effective in cancer treatment and new modalities with more potential effects on both CSCs and tumor cells are essential.

\section{Acknowledgements This research was carried out without funding.}

Conflicts of interest The authors have no relevant affiliation or financial involvement with any organization or entity with a financial interest in or financial conflict with the subject matter or materials discussed in the manuscript.

\section{References}

1. Perez-Herrero E, Fernandez-Medarde A. Advanced targeted therapies in cancer: drug nanocarriers, the future of chemotherapy. Eur J Pharm Biopharm. 2015;93:52-79.
2. Shaffer BC, Gillet JP, Patel C, Baer MR, Bates SE, Gottesman MM. Drug resistance: still a daunting challenge to the successful treatment of AML. Drug Resist Updat. 2012;15(1-2):62-9.

3. Hojjat-Farsangi M. Novel and emerging targeted-based cancer therapy agents and methods. Tumour Biol. 2015;36(2):543-56.

4. Hojjat-Farsangi M. Small-molecule inhibitors of the receptor tyrosine kinases: promising tools for targeted cancer therapies. Int $\mathrm{J}$ Mol Sci. 2014;15(8):13768-801.

5. Shabani M, Hojjat-Farsangi M. Targeting receptor tyrosine kinases using monoclonal antibodies: the most specific tools for targeted-based cancer therapy. Curr Drug Targets. 2015 [Epub ahead of print].

6. Hojjat-Farsangi M. Targeting non-receptor tyrosine kinases using small molecule inhibitors: an overview of recent advances. J Drug Target. 2016;24(3):192-211.

7. Hovland R, Gjertsen BT, Bruserud O. Acute myelogenous leukemia with internal tandem duplication of the Flt3 gene appearing or altering at the time of relapse: a report of two cases. Leuk Lymphoma. 2002;43(10):2027-9.

8. Awasthi S, Singhal SS, Singhal J, Yang Y, Zimniak P, Awasthi YC. Role of RLIP76 in lung cancer doxorubicin resistance: III. Anti-RLIP76 antibodies trigger apoptosis in lung cancer cells and synergistically increase doxorubicin cytotoxicity. Int J Oncol. 2003;22(4):721-32.

9. Holohan C, Van Schaeybroeck S, Longley DB, Johnston PG. Cancer drug resistance: an evolving paradigm. Nat Rev Cancer. 2013;13(10):714-26.

10. Meacham CE, Morrison SJ. Tumour heterogeneity and cancer cell plasticity. Nature. 2013;501(7467):328-37.

11. Alaoui-Jamali MA, Morand GB, da Silva SD. ErbB polymorphisms: insights and implications for response to targeted cancer therapeutics. Front Genet. 2015;6:17.

12. Yap TA, Gerlinger M, Futreal PA, Pusztai L, Swanton C. Intratumor heterogeneity: seeing the wood for the trees. Sci Transl Med. 2012;4(127):127ps110.

13. Bouwman P, Jonkers J. The effects of deregulated DNA damage signalling on cancer chemotherapy response and resistance. Nat Rev Cancer. 2012;12(9):587-98.

14. Farmer H, McCabe N, Lord CJ, Tutt AN, Johnson DA, Richardson TB, et al. Targeting the DNA repair defect in BRCA mutant cells as a therapeutic strategy. Nature. 2005;434(7035): 917-21.

15. Kratimenos P, Koutroulis I, Marconi D, Syriopoulou V, DelivoriaPapadopoulos M, Chrousos GP, et al. Multi-targeted molecular therapeutic approach in aggressive neuroblastoma: the effect of Focal Adhesion Kinase-Src-Paxillin system. Expert Opin Ther Targets. 2014;18(12):1395-406.

16. Bagrodia S, Smeal T, Abraham RT. Mechanisms of intrinsic and acquired resistance to kinase-targeted therapies. Pigment Cell Melanoma Res. 2012;25(6):819-31.

17. Zhang L, Tong X, Li J, Huang Y, Hu X, Chen Y, et al. Apoptotic and autophagic pathways with relevant small-molecule compounds, in cancer stem cells. Cell Prolif. 2015;48(4):385-97.

18. Wolfson B, Eades G, Zhou Q. Adipocyte activation of cancer stem cell signaling in breast cancer. World J Biol Chem. 2015;6(2):39 47.

19. Shah K, Bradbury NA. Lemur tyrosine kinase 2, a novel target in prostate cancer therapy. Oncotarget. 2015;6(16):14233-46.

20. Shackleton M. Normal stem cells and cancer stem cells: similar and different. Semin Cancer Biol. 2010;20(2):85-92.

21. Tavazoie M, Van der Veken L, Silva-Vargas V, Louissaint M, Colonna L, Zaidi B, et al. A specialized vascular niche for adult neural stem cells. Cell Stem Cell. 2008;3(3):279-88.

22. Phesse TJ, Clarke AR. Normal stem cells in cancer prone epithelial tissues. Br J Cancer. 2009;100(2):221-7. 
23. Li L, Neaves WB. Normal stem cells and cancer stem cells: the niche matters. Cancer Res. 2006;66(9):4553-7.

24. Al-Hajj M, Wicha MS, Benito-Hernandez A, Morrison SJ, Clarke MF. Prospective identification of tumorigenic breast cancer cells. Proc Natl Acad Sci U S A. 2003;100(7):3983-8.

25. Lim E, Vaillant F, Wu D, Forrest NC, Pal B, Hart AH, et al. Aberrant luminal progenitors as the candidate target population for basal tumor development in BRCA1 mutation carriers. Nat Med. 2009;15(8):907-13.

26. Civin CI, Strauss LC, Brovall C, Fackler MJ, Schwartz JF, Shaper $\mathrm{JH}$. Antigenic analysis of hematopoiesis. III. A hematopoietic progenitor cell surface antigen defined by a monoclonal antibody raised against KG-1a cells. J Immunol. 1984;133(1):157-65.

27. Lapidot T, Sirard C, Vormoor J, Murdoch B, Hoang T, CaceresCortes J, et al. A cell initiating human acute myeloid leukaemia after transplantation into SCID mice. Nature. 1994;367(6464): 645-8.

28. Malanchi I, Peinado H, Kassen D, Hussenet T, Metzger D, Chambon $\mathrm{P}$, et al. Cutaneous cancer stem cell maintenance is dependent on beta-catenin signalling. Nature. 2008;452(7187): 650-3.

29. Cozzio A, Passegue E, Ayton PM, Karsunky H, Cleary ML, Weissman IL. Similar MLL-associated leukemias arising from self-renewing stem cells and short-lived myeloid progenitors. Genes Dev. 2003;17(24):3029-35.

30. Krivtsov AV, Twomey D, Feng Z, Stubbs MC, Wang Y, Faber J, et al. Transformation from committed progenitor to leukaemia stem cell initiated by MLL-AF9. Nature. 2006;442(7104):818-22.

31. Davies S, Beckenkamp A, Buffon A. CD26 a cancer stem cell marker and therapeutic target. Biomed Pharmacother. 2015;71: 135-8.

32. Chan WI, Huntly BJ. Leukemia stem cells in acute myeloid leukemia. Semin Oncol. 2008;35(4):326-35.

33. Bonnet D, Dick JE. Human acute myeloid leukemia is organized as a hierarchy that originates from a primitive hematopoietic cell. Nat Med. 1997;3(7):730-7.

34. Jordan CT. Unique molecular and cellular features of acute myelogenous leukemia stem cells. Leukemia. 2002;16(4):559-62.

35. Herrmann H, Sadovnik I, Cerny-Reiterer S, Rulicke T, Stefanzl G, Willmann M, et al. Dipeptidylpeptidase IV (CD26) defines leukemic stem cells (LSC) in chronic myeloid leukemia. Blood. 2014;123(25):3951-62.

36. Hauswirth AW, Florian S, Printz D, Sotlar K, Krauth MT, Fritsch $\mathrm{G}$, et al. Expression of the target receptor CD33 in CD34+/CD38-/ CD123+ AML stem cells. Eur J Clin Invest. 2007;37(1):73-82.

37. Cox CV, Diamanti P, Evely RS, Kearns PR, Blair A. Expression of CD133 on leukemia-initiating cells in childhood ALL. Blood. 2009;113(14):3287-96.

38. Moro M, Bertolini G, Pastorino U, Roz L, Sozzi G. Combination treatment with all-trans retinoic acid prevents cisplatin-induced enrichment of CD133+ tumor-initiating cells and reveals heterogeneity of cancer stem cell compartment in lung cancer. J Thorac Oncol. 2015;10(7):1027-36.

39. Cioffi M, D'Alterio C, Camerlingo R, Tirino V, Consales C, Riccio A, et al. Identification of a distinct population of CD133CXCR4 cancer stem cells in ovarian cancer. Sci Rep. 2015;5:10357.

40. Avilion AA, Nicolis SK, Pevny LH, Perez L, Vivian N, LovellBadge R. Multipotent cell lineages in early mouse development depend on SOX2 function. Genes Dev. 2003;17(1):126-40.

41. Pesce M, Scholer HR. Oct-4: gatekeeper in the beginnings of mammalian development. Stem Cells. 2001;19(4):271-8.

42. Mitsui K, Tokuzawa Y, Itoh H, Segawa K, Murakami M, Takahashi K, et al. The homeoprotein Nanog is required for maintenance of pluripotency in mouse epiblast and ES cells. Cell. 2003;113(5):631-42.
43. Kumar SM, Liu S, Lu H, Zhang H, Zhang PJ, Gimotty PA, et al. Acquired cancer stem cell phenotypes through Oct4-mediated dedifferentiation. Oncogene. 2012;31(47):4898-911.

44. Luo W, Li S, Peng B, Ye Y, Deng X, Yao K. Embryonic stem cells markers SOX2, OCT4 and Nanog expression and their correlations with epithelial-mesenchymal transition in nasopharyngeal carcinoma. PLoS One. 2013;8(2): e56324.

45. Singh SK, Hawkins C, Clarke ID, Squire JA, Bayani J, Hide T, et al. Identification of human brain tumour initiating cells. Nature. 2004;432(7015):396-401.

46. O'Brien CA, Pollett A, Gallinger S, Dick JE. A human colon cancer cell capable of initiating tumour growth in immunodeficient mice. Nature. 2007;445(7123):106-10.

47. Joo KM, Kim SY, Jin X, Song SY, Kong DS, Lee JI, et al. Clinical and biological implications of CD133-positive and CD133negative cells in glioblastomas. Lab Invest. 2008;88(8):808-15.

48. Wang J, Sakariassen PO, Tsinkalovsky O, Immervoll H, Boe SO, Svendsen A, et al. CD133 negative glioma cells form tumors in nude rats and give rise to CD133 positive cells. Int J Cancer. 2008;122(4):761-8.

49. Chu P, Clanton DJ, Snipas TS, Lee J, Mitchell E, Nguyen ML, et al. Characterization of a subpopulation of colon cancer cells with stem cell-like properties. Int J Cancer. 2009;124(6):1312-21.

50. Murakami S, Ninomiya W, Sakamoto E, Shibata T, Akiyama H, Tashiro F. SRY and OCT4 are required for the acquisition of cancer stem cell-like properties and are potential differentiation therapy targets. Stem Cells. 2015;33:2652-63.

51. Neradil J, Veselska R. Nestin as a marker of cancer stem cells. Cancer Sci. 2015;106:803-11.

52. Holmberg J, He X, Peredo I, Orrego A, Hesselager G, Ericsson C, et al. Activation of neural and pluripotent stem cell signatures correlates with increased malignancy in human glioma. PLoS One. 2011;6(3):e18454.

53. Thies S, Friess M, Frischknecht L, Korol D, Felley-Bosco E, Stahel R, et al. Expression of the stem cell factor nestin in malignant pleural mesothelioma is associated with poor prognosis. PLoS One. 2015;10(9):e0139312.

54. Strojnik T, Rosland GV, Sakariassen PO, Kavalar R, Lah T. Neural stem cell markers, nestin and musashi proteins, in the progression of human glioma: correlation of nestin with prognosis of patient survival. Surg Neurol. 2007;68(2):133-43. discussion 143-134.

55. Wang W, Dong LP, Zhang N, Zhao CH. Role of cancer stem cell marker CD44 in gastric cancer: a meta-analysis. Int J Clin Exp Med. 2014;7(12):5059-66.

56. Klopfleisch R, Kohn B, Gruber AD. Mechanisms of tumour resistance against chemotherapeutic agents in veterinary oncology. Vet J. 2016;207:63-72.

57. Moghbeli M, Moaven O, Memar B, Raziei HR, Aarabi A, Dadkhah E, et al. Role of hMLH1 and E-cadherin promoter methylation in gastric cancer progression. J Gastrointest Cancer. 2014;45(1):40-7.

58. Rossi C, Poli P, Candi A, Buschini A. Modulation of mitomycin C mutagenicity on Saccharomyces cerevisiae by glutathione, cytochrome P-450, and mitochondria interactions. Mutat Res. 1997;390(1-2):113-20.

59. Marie JP, Simonin G, Legrand O, Delmer A, Faussat AM, Lewis $\mathrm{AD}$, et al. Glutathione-S-transferases pi, alpha, mu and mdr1 mRNA expression in normal lymphocytes and chronic lymphocytic leukemia. Leukemia. 1995;9(10):1742-7.

60. Lewis DF. 57 varieties: the human cytochromes P450. Pharmacogenomics. 2004;5(3):305-18.

61. Kaufman Y, Ifergan I, Rothem L, Jansen G, Assaraf YG. Coexistence of multiple mechanisms of PT523 resistance in human leukemia cells harboring 3 reduced folate carrier alleles: transcriptional silencing, inactivating mutations, and allele loss. Blood. 2006;107(8):3288-94. 
62. Chatterjee S, Damle SG, Sharma AK. Mechanisms of resistance against cancer therapeutic drugs. Curr Pharm Biotechnol. 2014;15(12):1105-12.

63. Kimchi-Sarfaty C, Oh JM, Kim IW, Sauna ZE, Calcagno AM, Ambudkar SV, et al. A "silent" polymorphism in the MDR1 gene changes substrate specificity. Science. 2007;315(5811):525-8.

64. Cascorbi I, Haenisch S. Pharmacogenetics of ATP-binding cassette transporters and clinical implications. Methods Mol Biol. 2010;596:95-121.

65. Fung KL, Gottesman MM. A synonymous polymorphism in a common MDR1 (ABCB1) haplotype shapes protein function. Biochim Biophys Acta. 2009;1794(5):860-71.

66. He L, Vasiliou K, Nebert DW. Analysis and update of the human solute carrier (SLC) gene superfamily. Hum Genomics. 2009;3(2): 195-206.

67. Mackenzie PI, Bock KW, Burchell B, Guillemette C, Ikushiro S, Iyanagi $\mathrm{T}$, et al. Nomenclature update for the mammalian UDP glycosyltransferase (UGT) gene superfamily. Pharmacogenet Genomics. 2005;15(10):677-85.

68. Nebert DW, Vasiliou V. Analysis of the glutathione S-transferase (GST) gene family. Hum Genomics. 2004;1(6):460-4

69. Plebuch M, Soldan M, Hungerer C, Koch L, Maser E. Increased resistance of tumor cells to daunorubicin after transfection of cDNAs coding for anthracycline inactivating enzymes. Cancer Lett. 2007;255(1):49-56.

70. Hoffmann F, Maser E. Carbonyl reductases and pluripotent hydroxysteroid dehydrogenases of the short-chain dehydrogenase/ reductase superfamily. Drug Metab Rev. 2007;39(1):87-144.

71. Forrest GL, Gonzalez B. Carbonyl reductase. Chem Biol Interact. 2000;129(1-2):21-40.

72. Yin SJ. Alcohol dehydrogenase: enzymology and metabolism. Alcohol Alcohol Suppl. 1994;2:113-9.

73. Vasiliou V, Nebert DW. Analysis and update of the human aldehyde dehydrogenase (ALDH) gene family. Hum Genomics. 2005;2(2):138-43

74. Panoutsopoulos GI, Kouretas D, Beedham C. Contribution of aldehyde oxidase, xanthine oxidase, and aldehyde dehydrogenase on the oxidation of aromatic aldehydes. Chem Res Toxicol. 2004;17(10):1368-76

75. Mitchell SC. Flavin mono-oxygenase (FMO) - the 'other' oxidase. Curr Drug Metab. 2008;9(4):280-4.

76. Gamage N, Barnett A, Hempel N, Duggleby RG, Windmill KF, Martin JL, et al. Human sulfotransferases and their role in chemical metabolism. Toxicol Sci. 2006;90(1):5-22.

77. Arand M, Cronin A, Adamska M, Oesch F. Epoxide hydrolases: structure, function, mechanism, and assay. Methods Enzymol. 2005;400:569-88.

78. Sousa D, Lima RT, Vasconcelos MH. Intercellular transfer of cancer drug resistance traits by extracellular vesicles. Trends Mol Med. 2015;21(10):595-608.

79. Takahashi K, Yan IK, Wood J, Haga H, Patel T. Involvement of extracellular vesicle long noncoding RNA (linc-VLDLR) in tumor cell responses to chemotherapy. Mol Cancer Res. 2014;12(10): 1377-87.

80. Gong J, Luk F, Jaiswal R, George AM, Grau GE, Bebawy M. Microparticle drug sequestration provides a parallel pathway in the acquisition of cancer drug resistance. Eur J Pharmacol. 2013;721(1-3):116-25

81. Corcoran C, Rani S, O’Brien K, O’Neill A, Prencipe M, Sheikh R, et al. Docetaxel-resistance in prostate cancer: evaluating associated phenotypic changes and potential for resistance transfer via exosomes. PLoS One. 2012;7(12):e50999.

82. Zhang FF, Zhu YF, Zhao QN, Yang DT, Dong YP, Jiang L, et al. Microvesicles mediate transfer of P-glycoprotein to paclitaxelsensitive A2780 human ovarian cancer cells, conferring paclitaxel-resistance. Eur J Pharmacol. 2014;738:83-90.
83. Lu JF, Luk F, Gong J, Jaiswal R, Grau GE, Bebawy M. Microparticles mediate MRP1 intercellular transfer and the retemplating of intrinsic resistance pathways. Pharmacol Res. 2013;76:77-83.

84. Kong JN, He Q, Wang G, Dasgupta S, Dinkins MB, Zhu G, et al. Guggulsterone and bexarotene induce secretion of exosomeassociated breast cancer resistance protein and reduce doxorubicin resistance in MDA-MB-231 cells. Int J Cancer. 2015;137(7): 1610-20.

85. Aung T, Chapuy B, Vogel D, Wenzel D, Oppermann M, Lahmann $\mathrm{M}$, et al. Exosomal evasion of humoral immunotherapy in aggressive B-cell lymphoma modulated by ATP-binding cassette transporter A3. Proc Natl Acad Sci U S A. 2011;108(37):15336-41.

86. Drummond MW, Holyoake TL. Tyrosine kinase inhibitors in the treatment of chronic myeloid leukaemia: so far so good? Blood Rev. 2001;15(2):85-95.

87. Palmberg C, Koivisto P, Hyytinen E, Isola J, Visakorpi T, Kallioniemi OP, et al. Androgen receptor gene amplification in a recurrent prostate cancer after monotherapy with the nonsteroidal potent antiandrogen Casodex (bicalutamide) with a subsequent favorable response to maximal androgen blockade. Eur Urol. 1997;31(2):216-9.

88. Lu Y, Zi X, Zhao Y, Mascarenhas D, Pollak M. Insulin-like growth factor-I receptor signaling and resistance to trastuzumab (Herceptin). J Natl Cancer Inst. 2001;93(24):1852-7.

89. Engelman JA, Zejnullahu K, Mitsudomi T, Song Y, Hyland C, Park JO, et al. MET amplification leads to gefitinib resistance in lung cancer by activating ERBB3 signaling. Science. 2007;316(5827):1039-43.

90. Hanahan D, Weinberg RA. Hallmarks of cancer: the next generation. Cell. 2011;144(5):646-74.

91. Miyashita T, Reed JC. bcl-2 gene transfer increases relative resistance of S49.1 and WEHI7.2 lymphoid cells to cell death and DNA fragmentation induced by glucocorticoids and multiple chemotherapeutic drugs. Cancer Res. 1992;52(19):5407-11.

92. Konopleva M, Contractor R, Tsao T, Samudio I, Ruvolo PP, Kitada S, et al. Mechanisms of apoptosis sensitivity and resistance to the $\mathrm{BH} 3$ mimetic ABT-737 in acute myeloid leukemia. Cancer Cell. 2006;10(5):375-88.

93. Oh Y, Swierczewska M, Kim TH, Lim SM, Eom HN, Park JH, et al. Delivery of tumor-homing TRAIL sensitizer with long-acting TRAIL as a therapy for TRAIL-resistant tumors. J Control Release. 2015;220(Pt B):671-681.

94. Souza PS, Madigan JP, Gillet JP, Kapoor K, Ambudkar SV, Maia $\mathrm{RC}$, et al. Expression of the multidrug transporter P-glycoprotein is inversely related to that of apoptosis-associated endogenous TRAIL. Exp Cell Res. 2015;336(2):318-28.

95. Trivedi R, Mishra DP. Trailing TRAIL resistance: novel targets for TRAIL sensitization in cancer cells. Front Oncol. 2015;5:69.

96. Pavet V, Portal MM, Moulin JC, Herbrecht R, Gronemeyer H. Towards novel paradigms for cancer therapy. Oncogene. 2011;30(1):1-20.

97. Fukuda S, Broxmeyer HE, Pelus LM. Flt3 ligand and the Flt3 receptor regulate hematopoietic cell migration by modulating the SDF-1alpha(CXCL12)/CXCR4 axis. Blood. 2005;105(8):311726.

98. Rombouts EJ, Pavic B, Lowenberg B, Ploemacher RE. Relation between CXCR-4 expression, Flt3 mutations, and unfavorable prognosis of adult acute myeloid leukemia. Blood. 2004;104(2): $550-7$.

99. Kojima K, McQueen T, Chen Y, Jacamo R, Konopleva M, Shinojima N, et al. p53 activation of mesenchymal stromal cells partially abrogates microenvironment-mediated resistance to FLT3 inhibition in AML through HIF-1alpha-mediated downregulation of CXCL12. Blood. 2011;118(16):4431-9. 
100. Weisberg E, Liu Q, Nelson E, Kung AL, Christie AL, Bronson R, et al. Using combination therapy to override stromal-mediated chemoresistance in mutant FLT3-positive AML: synergism between FLT3 inhibitors, dasatinib/multi-targeted inhibitors and JAK inhibitors. Leukemia. 2012;26(10):2233-44.

101. Gameiro SR, Caballero JA, Hodge JW. Defining the molecular signature of chemotherapy-mediated lung tumor phenotype modulation and increased susceptibility to T-cell killing. Cancer Biother Radiopharm. 2012;27(1):23-35.

102. Fiszman GL, Jasnis MA. Molecular mechanisms of trastuzumab resistance in HER2 overexpressing breast cancer. Int J Breast Cancer. 2011;2011:352182.

103. Price-Schiavi SA, Jepson S, Li P, Arango M, Rudland PS, Yee L, et al. Rat Muc4 (sialomucin complex) reduces binding of antiErbB2 antibodies to tumor cell surfaces, a potential mechanism for herceptin resistance. Int J Cancer. 2002;99(6):783-91.

104. Carraway KL, Price-Schiavi SA, Komatsu M, Jepson S, Perez A, Carraway CA. Muc4/sialomucin complex in the mammary gland and breast cancer. J Mammary Gland Biol Neoplasia. 2001;6(3): 323-37.

105. Akiyama T, Matsuda S, Namba Y, Saito T, Toyoshima K, Yamamoto $\mathrm{T}$. The transforming potential of the c-erbB-2 protein is regulated by its autophosphorylation at the carboxyl-terminal domain. Mol Cell Biol. 1991;11(2):833-42.

106. Nagy P, Friedlander E, Tanner M, Kapanen AI, Carraway KL, Isola $J$, et al. Decreased accessibility and lack of activation of ErbB2 in JIMT-1, a herceptin-resistant, MUC4-expressing breast cancer cell line. Cancer Res. 2005;65(2):473-82.

107. Brooks MD, Burness ML, Wicha MS. Therapeutic implications of cellular heterogeneity and plasticity in breast cancer. Cell Stem Cell. 2015;17(3):260-71.

108. Rycaj K, Tang DG. Cell-of-origin of cancer versus cancer stem cells: assays and interpretations. Cancer Res. 2015;75(19):400311.

109. Ramachandran K, Speer C, Nathanson L, Claros M, Singal R. Role of DNA methylation in cabazitaxel resistance in prostate cancer. Anticancer Res. 2016;36(1):161-8.

110. Nogales V, Reinhold WC, Varma S, Martinez-Cardus A, Moutinho C, Moran S, et al. Epigenetic inactivation of the putative DNA/RNA helicase SLFN11 in human cancer confers resistance to platinum drugs. Oncotarget. 2015;7(3):3084-97.

111. Ding B, Wang Z, Jiang X, Li X, Wang C, Zhong Q, et al. Palliative chemotherapy followed by methylation inhibitor in high-risk acute myeloid leukemia: an in vitro and clinical study. Mol Clin Oncol. 2015;3(5):1139-44.

112. Yu G, Xie X, Sun D, Geng J, Fu F, Zhang L, et al. EGFR mutation L747P led to gefitinib resistance and accelerated liver metastases in a Chinese patient with lung adenocarcinoma. Int J Clin Exp Pathol. 2015;8(7):8603-6.

113. Zhou J, Zheng J, Zhao J, Sheng Y, Ding W. Poor response to gefitinib in lung adenocarcinoma with concomitant epidermal growth factor receptor mutation and anaplastic lymphoma kinase rearrangement. Thorac Cancer. 2015;6(2):216-9.

114. Khan NA, Mirshahidi S, Mirshahidi HR. A novel insertion mutation on exon 20 of epidermal growth factor receptor, conferring resistance to erlotinib. Case Rep Oncol. 2014;7(2):491-6.

115. Zhang J, Yang PL, Gray NS. Targeting cancer with small molecule kinase inhibitors. Nat Rev Cancer. 2009;9(1):28-39.

116. Sierra JR, Cepero V, Giordano S. Molecular mechanisms of acquired resistance to tyrosine kinase targeted therapy. Mol Cancer. 2010;9:75.

117. Hochhaus A, La Rosee P. Imatinib therapy in chronic myelogenous leukemia: strategies to avoid and overcome resistance. Leukemia. 2004;18(8):1321-31.

118. Melo JV, Chuah C. Resistance to imatinib mesylate in chronic myeloid leukaemia. Cancer Lett. 2007;249(2):121-32.
119. O’Hare T, Walters DK, Stoffregen EP, Jia T, Manley PW, Mestan $\mathrm{J}$, et al. In vitro activity of Bcr-Abl inhibitors AMN107 and BMS354825 against clinically relevant imatinib-resistant Abl kinase domain mutants. Cancer Res. 2005;65(11):4500-5.

120. Murray LJ, Abrams TJ, Long KR, Ngai TJ, Olson LM, Hong W, et al. SU11248 inhibits tumor growth and CSF-1R-dependent osteolysis in an experimental breast cancer bone metastasis model. Clin Exp Metastasis. 2003;20(8):757-66.

121. Pricl S, Fermeglia M, Ferrone M, Tamborini E. T315I-mutated Bcr-Abl in chronic myeloid leukemia and imatinib: insights from a computational study. Mol Cancer Ther. 2005;4(8):1167-74.

122. Shiotsu Y, Kiyoi H, Ishikawa Y, Tanizaki R, Shimizu M, Umehara $\mathrm{H}$, et al. KW-2449, a novel multikinase inhibitor, suppresses the growth of leukemia cells with FLT3 mutations or T315I-mutated BCR/ABL translocation. Blood. 2009;114(8):1607-17.

123. de Silva CM, Reid R. Gastrointestinal stromal tumors (GIST): Ckit mutations, CD117 expression, differential diagnosis and targeted cancer therapy with Imatinib. Pathol Oncol Res. 2003;9(1):13-9.

124. Sleijfer S, Wiemer E, Seynaeve C, Verweij J. Improved insight into resistance mechanisms to imatinib in gastrointestinal stromal tumors: a basis for novel approaches and individualization of treatment. Oncologist. 2007;12(6):719-26.

125. Loughrey MB, Waring PM, Dobrovic A, Demetri G, Kovalenko $\mathrm{S}, \mathrm{McArthur}$ G. Polyclonal resistance in gastrointestinal stromal tumor treated with sequential kinase inhibitors. Clin Cancer Res. 2006;12(20 Pt 1):6205-6. author reply 6206-6207.

126. Heidel F, Solem FK, Breitenbuecher F, Lipka DB, Kasper S, Thiede $\mathrm{MH}$, et al. Clinical resistance to the kinase inhibitor PKC412 in acute myeloid leukemia by mutation of Asn-676 in the FLT3 tyrosine kinase domain. Blood. 2006;107(1):293-300.

127. Zhong L, Jia YQ, Meng WT, Ni X. FMS-like tyrosine kinase 3 internal tandem duplication and the patterns of its gene sequence in 207 Chinese patients with de novo acute myeloid leukemia. Arch Pathol Lab Med. 2012;136(1):84-9.

128. Lierman E, Michaux L, Beullens E, Pierre P, Marynen P, Cools J, et al. FIP1L1-PDGFRalpha D842V, a novel panresistant mutant, emerging after treatment of FIP1L1-PDGFRalpha T674I eosinophilic leukemia with single agent sorafenib. Leukemia. 2009;23(5):845-51.

129. Kloos RT, Ringel MD, Knopp MV, Hall NC, King M, Stevens R, et al. Phase II trial of sorafenib in metastatic thyroid cancer. J Clin Oncol. 2009;27(10): 1675-84.

130. Nelson MH, Dolder CR. Lapatinib: a novel dual tyrosine kinase inhibitor with activity in solid tumors. Ann Pharmacother. 2006;40(2):261-9.

131. Trowe T, Boukouvala S, Calkins K, Cutler Jr RE, Fong R, Funke R, et al. EXEL-7647 inhibits mutant forms of ErbB2 associated with lapatinib resistance and neoplastic transformation. Clin Cancer Res. 2008;14(8):2465-75.

132. Carillio G, Montanino A, Costanzo R, Sandomenico C, Piccirillo $\mathrm{MC}$, Di Maio M, et al. Cetuximab in non-small-cell lung cancer. Expert Rev Anticancer Ther. 2012;12(2):163-75.

133. Janjigian YY, Smit EF, Groen HJ, Horn L, Gettinger S, Camidge DR, et al. Dual inhibition of EGFR with afatinib and cetuximab in kinase inhibitor-resistant EGFR-mutant lung cancer with and without T790M mutations. Cancer Discov. 2014;4(9):1036-45.

134. Kavuri SM, Jain N, Galimi F, Cottino F, Leto SM, Migliardi G, et al. HER2 activating mutations are targets for colorectal cancer treatment. Cancer Discov. 2015;5(8):832-41.

135. Kwak EL, Bang YJ, Camidge DR, Shaw AT, Solomon B, Maki $\mathrm{RG}$, et al. Anaplastic lymphoma kinase inhibition in non-smallcell lung cancer. N Engl J Med. 2010;363(18):1693-703.

136. Tani T, Yasuda H, Hamamoto J, Kuroda A, Arai D, Ishioka K, et al. Activation of EGFR bypass signaling by TGFalpha overexpression induces acquired resistance to alectinib in ALK- 
translocated lung cancer cells. Mol Cancer Ther. 2016;15(1):16271.

137. Katayama R, Friboulet L, Koike S, Lockerman EL, Khan TM, Gainor JF, et al. Two novel ALK mutations mediate acquired resistance to the next-generation ALK inhibitor alectinib. Clin Cancer Res. 2014;20(22):5686-96.

138. Woyach JA, Furman RR, Liu TM, Ozer HG, Zapatka M, Ruppert AS, et al. Resistance mechanisms for the Bruton's tyrosine kinase inhibitor ibrutinib. N Engl J Med. 2014;370(24):2286-94.

139. Kokhaei P, Jadidi-Niaragh F, Sotoodeh Jahromi A, Osterborg A, Mellstedt H, Hojjat-Farsangi M. Ibrutinib-A double-edge sword in cancer and autoimmune disorders. J Drug Target. 2015 [Epub ahead of print].

140. Byrd JC, Harrington B, O'Brien S, Jones JA, Schuh A, Devereux S, et al. Acalabrutinib (ACP-196) in relapsed chronic lymphocytic leukemia. N Engl J Med. 2016;374(4):323-32.

141. Gray GK, McFarland BC, Nozell SE, Benveniste EN. NF-kappaB and STAT3 in glioblastoma: therapeutic targets coming of age. Expert Rev Neurother. 2014;14(11):1293-306.

142. Zhang W, Gao C, Konopleva M, Chen Y, Jacamo RO, Borthakur $\mathrm{G}$, et al. Reversal of acquired drug resistance in FLT3-mutated acute myeloid leukemia cells via distinct drug combination strategies. Clin Cancer Res. 2014;20(9):2363-74.

143. Martins-Neves SR, Paiva-Oliveira DI, Wijers-Koster PM, Abrunhosa AJ, Fontes-Ribeiro C, Bovee JV, et al. Chemotherapy induces stemness in osteosarcoma cells through activation of Wnt/beta-catenin signaling. Cancer Lett. 2016;370(2):286-95.

144. Duchartre Y, Kim YM, Kahn M. The Wnt signaling pathway in cancer. Crit Rev Oncol Hematol. 2015 [Epub ahead of print].

145. Ma S, Yang LL, Niu T, Cheng C, Zhong L, Zheng MW, et al. SKLB-677, an FLT3 and Wnt/beta-catenin signaling inhibitor, displays potent activity in models of FLT3-driven AML. Sci Rep. 2015;5:15646.

146. Wang W, Zhong W, Yuan J, Yan C, Hu S, Tong Y, et al. Involvement of Wnt/beta-catenin signaling in the mesenchymal stem cells promote metastatic growth and chemoresistance of cholangiocarcinoma. Oncotarget. 2015;6(39):42276-89.

147. Franqui-Machin R, Wendlandt EB, Janz S, Zhan F, Tricot G. Cancer stem cells are the cause of drug resistance in multiple myeloma: fact or fiction? Oncotarget. 2015;6(38):40496-506.

148. Lee J, Bartholomeusz C, Mansour O, Humphries J, Hortobagyi $\mathrm{GN}$, Ordentlich P, et al. A class I histone deacetylase inhibitor, entinostat, enhances lapatinib efficacy in HER2-overexpressing breast cancer cells through FOXO3-mediated Bim1 expression. Breast Cancer Res Treat. 2014;146(2):259-72.

149. Nguyen NP, Almeida FS, Chi A, Nguyen LM, Cohen D, Karlsson $\mathrm{U}$, et al. Molecular biology of breast cancer stem cells: potential clinical applications. Cancer Treat Rev. 2010;36(6):485-91.

150. Huang L, Fu L. Mechanisms of resistance to EGFR tyrosine kinase inhibitors. Acta Pharm Sin B. 2015;5(5):390-401.

151. Tekiner TA, Basaga H. Role of microRNA deregulation in breast cancer cell chemoresistance and stemness. Curr Med Chem. 2013;20(27):3358-69.

152. Kutanzi KR, Yurchenko OV, Beland FA, Checkhun VF, Pogribny IP. MicroRNA-mediated drug resistance in breast cancer. Clin Epigenetics. 2011;2(2):171-85.

153. Tan L, Yu JT. Causes and consequences of MicroRNA dysregulation in neurodegenerative diseases. Mol Neurobiol. 2015;51(3): $1249-62$

154. Jung EJ, Santarpia L, Kim J, Esteva FJ, Moretti E, Buzdar AU, et al. Plasma microRNA 210 levels correlate with sensitivity to trastuzumab and tumor presence in breast cancer patients. Cancer. 2012;118(10):2603-14.

155. Zhou JY, Chen X, Zhao J, Bao Z, Zhang P, Liu ZF. MicroRNA34a overcomes HGF-mediated gefitinib resistance in EGFR mutant lung cancer cells partly by targeting MET. Cancer Lett. 2014;351(2):265-71.

156. Ge X, Zheng L, Huang M, Wang Y, Bi F. MicroRNA expression profiles associated with acquired gefitinib-resistance in human lung adenocarcinoma cells. Mol Med Rep. 2015;11(1):333-40.

157. Daneshmanesh AH, Hojjat-Farsangi M, Khan AS, Jeddi-Tehrani M, Akhondi MM, Bayat AA, et al. Monoclonal antibodies against ROR1 induce apoptosis of chronic lymphocytic leukemia (CLL) cells. Leukemia. 2012;26(6):1348-55.

158. Hojjat-Farsangi M, Ghaemimanesh F, Daneshmanesh AH, Bayat AA, Mahmoudian J, Jeddi-Tehrani M, et al. Inhibition of the receptor tyrosine kinase ROR1 by anti-ROR1 monoclonal antibodies and siRNA induced apoptosis of melanoma cells. PLoS One. 2013;8(4):e61167.

159. Daneshmanesh AH, Hojjat-Farsangi M, Moshfegh A, Khan AS, Mikaelsson E, Osterborg A, et al. The PI3K/AKT/mTOR pathway is involved in direct apoptosis of CLL cells induced by ROR1 monoclonal antibodies. Br J Haematol. 2015;169(3):455-8.

160. Hojjat-Farsangi M, Moshfegh A, Daneshmanesh AH, Khan AS, Mikaelsson E, Osterborg A, et al. The receptor tyrosine kinase ROR1 - an oncofetal antigen for targeted cancer therapy. Semin Cancer Biol. 2014;29:21-31.

161. Hojjat-Farsangi M, Khan AS, Daneshmanesh AH, Moshfegh A, Sandin A, Mansouri L, et al. The tyrosine kinase receptor ROR1 is constitutively phosphorylated in chronic lymphocytic leukemia (CLL) cells. PLoS One. 2013;8(10):e78339.

162. Hojjat-Farsangi M, Jeddi-Tehrani M, Daneshmanesh AH, Mozaffari F, Moshfegh A, Hansson L, et al. Spontaneous immunity against the receptor tyrosine kinase ROR1 in patients with chronic lymphocytic leukemia. PLoS One. 2015;10(11): e0142310.

163. Daneshmanesh AH, Porwit A, Hojjat-Farsangi M, Jeddi-Tehrani M, Tamm KP, Grander D, et al. Orphan receptor tyrosine kinases ROR 1 and ROR2 in hematological malignancies. Leuk Lymphoma. 2013;54(4):843-50.

164. Bicocca VT, Chang BH, Masouleh BK, Muschen M, Loriaux MM, Druker BJ, et al. Crosstalk between ROR1 and the Pre-B cell receptor promotes survival of $\mathrm{t}(1 ; 19)$ acute lymphoblastic leukemia. Cancer Cell. 2012;22(5):656-67.

165. Zhu Y, Choi SH, Shah K. Multifunctional receptor-targeting antibodies for cancer therapy. Lancet Oncol. 2015;16(15):e543-54.

166. Vogel CL, Cobleigh MA, Tripathy D, Gutheil JC, Harris LN, Fehrenbacher L, et al. Efficacy and safety of trastuzumab as a single agent in first-line treatment of HER2-overexpressing metastatic breast cancer. J Clin Oncol. 2002;20(3):719-26.

167. Nahta R, Esteva FJ. HER2 therapy: molecular mechanisms of trastuzumab resistance. Breast Cancer Res. 2006;8(6):215.

168. Ortiz-Tudela E, Mteyrek A, Ballesta A, Innominato PF, Levi F. Cancer chronotherapeutics: experimental, theoretical, and clinical aspects. Handb Exp Pharmacol. 2013;217:261-88.

169. Reinberg AE. Concepts in chronopharmacology. Annu Rev Pharmacol Toxicol. 1992;32:51-66.

170. Wang P, An F, Zhuang X, Liu J, Zhao L, Zhang B, et al. Chronopharmacology and mechanism of antitumor effect of erlotinib in Lewis tumor-bearing mice. PLoS One. 2014;9(7): e101720. 